\title{
Floristic composition, structure and soil-vegetation relations in three white-sand soil patches in central Amazonia
}

\author{
Layon Oreste DEMARCHI ${ }^{1, *}$, Veridiana Vizoni SCUDELLER ${ }^{2}$, Livia Carvalho MOURA ${ }^{3}$, \\ Randolpho Gonçalves DIAS-TERCEIRO ${ }^{1}$, Aline LOPES ${ }^{1,4}$, Florian Karl WITTMANN ${ }^{1,5}$, \\ Maria Teresa Fernandez PIEDADE ${ }^{1}$ \\ Instituto Nacional de Pesquisas da Amazônia - INPA, Av. André Araújo 2936, Aleixo, Manaus, AM, Brasil \\ 2 Universidade Federal do Amazonas - UFAM, Instituto de Ciências Biológicas - ICB, Av. General Rodrigo Otávio Jordão Ramos 3000, Aleixo, Manaus, AM, Brasil \\ ${ }^{3}$ Universidade de Brasília - UnB, Departamento de Ecologia, Campus Darcy Ribeiro, Asa Norte, Brasília, DF, Brasil \\ ${ }^{4}$ Universidade Nilton Lins, Av. Professor Nilton Lins 3259, Parque das Laranjeiras, Manaus, AM, Brasil \\ Karlsruher Institut für Technologie - KIT, 76131 Karlsruhe, Germany \\ * Corresponding author: layon.lod@gmail.com
}

\begin{abstract}
The Amazonian white-sand vegetation presents a set of unique features, such as the dominance of a few species, high endemism and low species richness, which differentiate it from other Amazonian forests. Soil parameters have long been recognized as the main drivers of white-sand vegetation (WSV) characteristics. However, how they influence the composition, richness and structure of this vegetation type is still poorly understood. In this study we investigated the variation in floristic composition between patches and the soil-vegetation relations in three central Amazonian WSV patches. We tested whether slight differences in soil properties are linked with differences in floristic composition, species richness and forest structure in adjacent patches. In each patch three plots of $50 \times 50 \mathrm{~m}$ were sampled (a total of $2.25 \mathrm{ha}$ ). Soil samples were collected for each plot. The sampling cutoff for arboreal individuals was DBH $\geq 5 \mathrm{~cm}$. We sampled a total of 3956 individuals belonging to 40 families and 140 species. In each patch only a few species were dominant, but the dominant species varied among patches. Differences among patches were significant, but plots in the same patch tended to have similar species composition. The variable sum of bases (SB) was directly related to species composition, however, species richness and forest structure were not related to soil parameters. Even small variations in soil parameters can change species composition in WSV, although these variations do not necessarily influence the richness and other structural parameters.
\end{abstract}

KEYWORDS: species richness, oligotrophic ecosystems, dominance, sum of bases

\section{Composição florística, estrutura e relação solo-vegetação em três áreas de campinarana na Amazônia central}

\section{RESUMO}

As campinaranas amazônicas apresentam uma série de características únicas, como a dominância de poucas espécies, alto grau de endemismos e baixa riqueza de espécies, que as diferenciam de outras formações florestais amazônicas. Parâmetros edáficos têm sido apontados como os principais responsáveis pelas características das campinaranas. Contudo, como estes parâmetros influenciam a composição, riqueza e estrutura deste tipo de vegetação ainda é pouco entendido. Neste estudo investigamos a variaçáo estrutural, a composição florística e a relação solo-vegetação em três áreas de campinarana na Amazônia central, com intuito de testar se pequenas diferenças nos parâmetros edáficos do solo estão relacionados com diferenças na composição, riqueza e estrutura do componente arbóreo em áreas de campinarana adjacentes. Em cada área foram amostradas três parcelas de 50 x $50 \mathrm{~m}$ (totalizando $2.25 \mathrm{ha}$ ), com o critério de inclusão para os indivíduos de DAP $\geq 5 \mathrm{~cm}$. Amostras de solo foram coletadas em cada parcela. $\mathrm{O}$ número total de indivíduos amostrados foi 3956, pertencendo a 40 famílias e 140 espécies. Em cada área poucas espécies foram dominantes, mas estas variaram entre as áreas. Diferenças entre as áreas foram significativas, porém parcelas da mesma área tenderam a ter composição florística similar. A variável soma de bases (SB) foi diretamente relacionada à composição de espécies; contudo, riqueza de espécies e estrutura florestal não foram relacionadas a nenhum dos parâmetros do solo amostrados. Concluimos que mesmo pequenas variaçóes nos parâmetros edáficos do solo podem mudar a composiçáo de espécies em campinaranas, embora esta variação não necessariamente influencie a riqueza e outros parâmetros estruturais da vegetação.

PALAVRAS-CHAVE: riqueza de espécies, ecossistemas oligotróficos, dominância, soma de bases

CITE AS: Demarchi, L.O.; Scudeller, V.V.; Moura, L.C.; Dias-Terceiro, R.G.; Lopes, A.; Wittmann, F.K.; Piedade, M.T.F. 2018. Floristic composition, structure and soil-vegetation relations in three white-sand soil patches in central Amazonia. Acta Amazonica 48: 46-56. 


\section{INTRODUCTION}

The Amazonian region is formed by a mosaic of landscapes with different floristic compositions. Each landscape diversity is related to a variety of habitat characteristics and species preferences (Pitman et al. 2001; Coronado et al. 2009; Junk et al. 2011). It is estimated that Amazonian forests contain between 12,500 and 16,000 tree species (Hubbell et al. 2008; ter Steege et al. 2013). The formations designated as white-sand vegetation (WSV) or campinarana (Veloso et al. 1991) constitute a peculiar phytophysiognomy in the Amazon region. Soils beneath whitesand vegetation are composed of heavily leached white-sand of very low fertility (Heyligers 1963; Anderson 1981; Luizão et al. 2007; Mendonça et al. 2015); the woody vegetation is scleromorphic and relatively poor in tree species compared to other Amazonian ecosystems (Vicentini 2004; Stropp et al. 2011,), but rich in endemisms (Janzen 1974; Anderson et al. 1975; Anderson 1981; Boubli 2002; Fine et al. 2010; Adeney et al. 2016; Fine and Baraloto 2016; Guevara et al. 2016).

Estimates of white-sand vegetation cover ranged from 64,000 $\mathrm{km}^{2}$ (Braga 1979) to $400,000 \mathrm{~km}^{2}$ (Prance and Daly 1989). However, more accurate mapping techniques with remote sensing suggest that the coverage might be larger, since surveys of the Negro River basin alone (where continuous areas of white-sand vegetation are common) estimated its coverage to be 104.000 $\mathrm{km}^{2}$ (Junk et al. 2011), and the most recent estimate of whitesand vegetation coverage in the Amazon basin is $334,879 \mathrm{~km}^{2}$ (Adeney et al. 2016). In many other Amazonian regions, whitesand vegetation distribution is isolated and island-like, a result of the fragmented nature of the distribution of the sandy soils on which this vegetation type occurs (Prance 1996).

The structure of white-sand vegetation varies from grassland and open areas, dominated by herbaceous plants, to open shrub and dense-canopy forest physiognomies (Veloso et al. 1991; IBGE 2012). Many white-sand soils have an underlying hardpan, where any increase in precipitation can quickly elevate the groundwater level, subjecting plants to waterlogging or hydric saturation periods (Richardt et al. 1975; Kubitzki 1989a; Franco and Dezzeo 1994). Because of this characteristic, some authors emphasize the comparatively high floristic similarity between white-sand vegetation and Amazonian black-water seasonally-flooded forest (igapó) (Kubitzki 1989a; Kubitzki 1989b; Damasco et al. 2013).

Oligotrophic soils and hydric saturation have been considered the main drivers of white-sand vegetation characteristics (Heyligers 1963; Pires and Prance 1985; Franco and Dezzeo 1994; Tiessen et al. 1994; Sobrado 2009), since they work as strong environmental filters for tree species establishment and distribution (Targhetta et al. 2015; Adeney et al. 2016). Studies show that white-sand vegetation areas with higher hydric saturation may present lower species richness and smaller individuals (Bongers et al. 1985; Franco and Dezzeo 1994; Targhetta et al. 2015), although under certain edaphic and topographic conditions hydric saturation may provide less adverse conditions for species establishment, thereby these conditions might have a positive effect on species richness and diversity (Damasco et al. 2013). Though soil properties are directly influenced by hydric saturation, soil texture and fertility have been considered the main factors causing structural and floristic variation of white-sand vegetation (Tiessen et al. 1994; Coomes and Grubb 1996; Coomes 1997; Damasco et al. 2013). However, there are few studies that investigated the role of small differences in soil nutrient concentration within this oligotrophic ecosystem.

To investigate the relationships between soil parameters and the composition and structural characteristics of the woody plant assemblage, three isolated patches of white-sand vegetation surrounded by upland forest (terra-firme) forest were studied to address the following questions: (1) are the patches different in assemblage composition and (2) if so, are such differences linked to soil characteristics?

\section{MATERIAL AND METHODS}

\section{Study Area}

WSV was studied in three areas within the Tupé Sustainable Development Reserve (SDR Tupé, Figure 1), located on the left margin of the Negro River, approximately $30 \mathrm{~km}$ west of the city of Manaus, in the state of Amazonas, Brazil. The SDR Tupé covers an area of 11.973 ha and, together with other protected areas, forms an important mosaic of protected habitats in the central Brazilian Amazon. The average annual rainfall in the region is $2,100 \mathrm{~mm}$, with a well defined rainy season (165-300 mm month $\left.{ }^{-1}\right)$ from November to May, and a dry season $\left(<65 \mathrm{~mm} \mathrm{month}^{-1}\right)$ from July to September. The average temperature is $27^{\circ} \mathrm{C}$, ranging between $18{ }^{\circ} \mathrm{C}$ and $37^{\circ} \mathrm{C}$ throughout the year, and average relative humidity is around 85\% (Radam Brasil 1978). The study area is inserted in the Igarapé Tarumã-mirim basin (a tributary of the Rio Negro). This region is largely covered by WSV areas, which are distributed in patches. The vegetation of the SDR Tupé is predominantly upland forest (terra-firme), with black water river floodplains forest (igapó) dominating the narrow riverine floodplain (Scudeller et al. 2005).

\section{Vegetation sampling}

Three white-sand forest patches (A, B and C) were selected within the SDR Tupé. The patches were 40 to 100 ha in size and were surrounded by terra-firme and/or igapó forest. In each patch three $50 \times 50 \mathrm{~m}$ plots were established, totalling 0.75 ha per patch, and 2.25 ha among the three patches. To avoid sampling transitional areas between WSV and surrounding forest formations, all plots were allocated in the central part of each white-sand forest patch, with a distance of 100 to 180 $\mathrm{m}$ among sampling plots within patches, and a distance of 3.5 to $4 \mathrm{~km}$ among patches. 

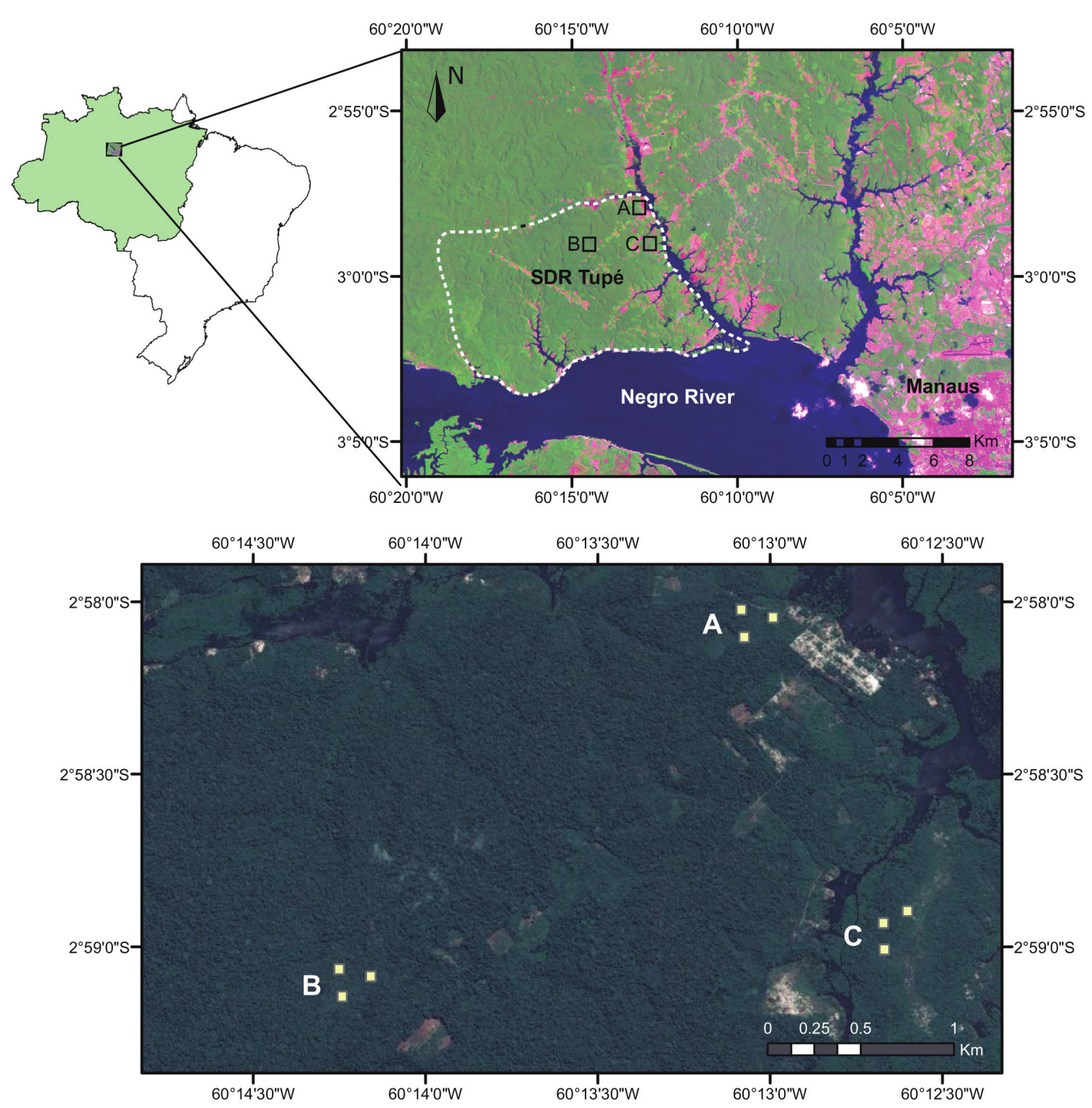

Figure 1. Map locating the white-sand forest patches studied (A, B and C) within the limits of the Tupé Sustainable Development Reserve (SDR Tupé), located on the left margin of the Negro River, west of the city of Manaus, in the state of Amazonas, Brazil. The nine sampling plots (three within each patch) are shown as nine squares in the larger image. The pink color on the smaller satellite image shows urbanized and clear-cut areas, while green shows forested habitats. This figure is in color in the electronic version.

All living woody individuals (except lianas), with diameter at breast height $(\mathrm{DBH}) \geq 5 \mathrm{~cm}$ were marked with numbered aluminum tags, and had their diameter measured. Tree height was estimated with a hypsometer. Vouchers from all individuals were collected, dried, pressed, and subsequently deposited in the herbarium of the National Institute of Amazon Research (Instituto Nacional de Pesquisas da Amazônia - INPA) and in the herbarium of the Federal Institute of Amazonas (Instituto Federal do Amazonas - IFAM) (EAFM). Species were identified using analytical keys, comparison with herbarium specimens and consulting specialists (see acknowledgements).
Species were classified according to APG IV (2016), and their names were standardized according to the classification of the REFLORA program.

\section{Chemical and physical soil characterization}

Soil samples at 0 to $20 \mathrm{~cm}$ depth were collected in the four corners and in the center of each sampling plot. The samples were homogenized in the field and joined in one composite sample per plot. The analyses were performed according to the Embrapa soil analysis protocol (Embrapa 1997). Twenty-four variables were analyzed: fine sand (0.2-0.05 $\mathrm{mm}$ grain diameter), 
coarse sand (2.0-0.2 mm), total sand $(2.0-0.05 \mathrm{~mm})$, silt $(0.05-$ $0.002 \mathrm{~mm}$ ) and clay $(>0.002 \mathrm{~mm}), \mathrm{C}$ (carbon), OM (organic matter), $\mathrm{pH}, \mathrm{P}, \mathrm{K}^{+}, \mathrm{Na}^{+}, \mathrm{Ca}^{2+}, \mathrm{Mg}^{2+}, \mathrm{Al}^{3+}, \mathrm{H}+\mathrm{AL}$ (potential acidity), $\mathrm{SB}$ (sum of bases: $\mathrm{Ca}^{2+}+\mathrm{Mg}^{2+}+\mathrm{K}^{+}+\mathrm{Na}^{+}$), $\mathrm{CEC}(\mathrm{t}$ ) (effective cation exchange capacity), $\mathrm{CEC}(\mathrm{T})$ (cation exchange capacity under neutral $\mathrm{pH}$ ), $\mathrm{V}$ (saturation index for bases), $\mathrm{m}$ (saturation index for aluminum), $\mathrm{Fe}, \mathrm{Zn}^{+}, \mathrm{Mn}^{2+}$ and $\mathrm{Cu}$.

\section{Data analysis}

The forest structure parameters Relative Density (RDe), Relative Dominance (RDo), Relative Frequency (RFr) and the Importance Value Index (IVI) (Curtis and McIntosh 1951) were calculated using the software Fitopac 2.1.2 (Shepperd 2010). To evaluate the local effect on species composition between the patches, two NMDS axes were generated and a MANOVA was applied to test for statistical difference in species composition among patches. Ranking was based on dissimilarity between samples (in a presence and absence matrix) calculated with the Jaccard Index (Borcard et al. 2011). To evaluate the effect of soil parameters in tree assemblages, we generated a new NMDS axis $(\mathrm{k}=1)$, based on dissimilarity between samples (in a presence and absence matrix) calculated with the Jaccard Index. The relationship between environmental variables and species composition was assessed using a Generalized Linear Mixed Model (GLMM). For the model, we used only variables that were not correlated with each other (see Supplementary Material, Table S1), as correlated variables carry the same information and could potentially mask or enhance patterns in additive multiple linear models (Magnusson and Mouráo 2005). We used the patches as a random variable. Therefore, our overall multiple regression model was: NMDS $=\mathrm{a}+\mathrm{b}\left(\mathrm{Mn}^{2+}\right)$ + b (Silt \%) + b (SB) + b (1 | patches).

To evaluate the effect of soil parameters on species richness and vegetation structure variation the GLMM was used separately for each parameter (species richness, relative density, average height and average basal area). Thus we used the same model (mentioned above) replacing the dependent variable for the vegetation structural parameters. To test the effects of soil variables on vegetation without the influence of the sampled patch, we included in the model the variable patches (study areas) as a random variable, so it was possible to control the effect of this variable and verify the real effect of the edaphic variables. All the multivariate analyses were performed using $\mathrm{R}$ vegan (R Core Team, 2014; Oksanen et al. 2013).

\section{RESULTS}

\section{Vegetation structural variation}

A total of 3956 trees belonging to 40 families and 140 species were recorded in the three patches (Table 1). The families with highest species richness were Fabaceae (15 species), Sapotaceae and Lauraceae (14 species each), Burseraceae, Moraceae and Myrtaceae (7 species each) and Sapindaceae (6 species).
The average DBH was $10.4 \mathrm{~cm}$, with a maximum of 94.2 $\mathrm{cm}$. Among the 36 individuals with DBH $>45 \mathrm{~cm}, 33$ were Aldina heterophylla Spruce ex Benth. The average height of individual trees was $7 \mathrm{~m}$, with some emergent individuals, mostly $A$. heterophylla, reaching $22 \mathrm{~m}$.

The highest similarity (41\%) occurred between patches A and B, followed by patches A and C (27\%) and B and C $(22 \%)$. Many species occurred only in one patch $(51.4 \%$ of all recorded species). Overall, the 10 most abundant species corresponded to $54.2 \%$ of recorded individuals. Likewise, the 10 most important species corresponded to $44.3 \%$ of the total IVI values. Only Aldina heterophylla was among the 10 most important (IVI) species in all three patches, and only Aspidosperma aff. verruculosum Müll.Arg., Clusia nemorosa G.Mey., Simaba guianensis Aubl., Pradosia schomburgkiana (A.DC.) Cronquist, and Conceveiba terminalis (Baill.) Müll. Arg. were among the 10 most important species in at least two of the sampled patches (Table 2). For 38 species only one individual was recorded, and for 13 species only two individuals. Together, these species corresponded to $36.4 \%$ of the total species richness. Phytosociological parameters and herbarium voucher numbers for all recorded species are available as Supplementary Material, Table S2.

Tree height and basal area differed significantly among sampling plots (ANOVA $\mathrm{F}=0.38 ; \mathrm{P}=0.00 ; \mathrm{F}=1.92 ; \mathrm{P}=$ 0.05 respectively) (Figure 2 ). However, only basal area differed significantly among patches (ANOVA $\mathrm{F}=4.45 ; \mathrm{P}=0.01$ ), due to a significant difference between patches $\mathrm{A}$ and $\mathrm{C}$ (Tukey test, $\mathrm{P}=0.01$ ). Plot ordination along the two NMDS axes captured $92.76 \%$ of the variation in species composition. Tree assemblages differed significantly among patches (MANOVA: Pillai trace $=1.5449 ; \mathrm{F}=10.182 ; \mathrm{P}<0.001)($ Figure 3).

Table 1. Number of individuals, families, richness (total number of species), number of rare species (only one or two recorded individuals) and number of exclusive species (present in only one patch) for nine sampling plots in three white-sand forest patches in Tupé Sustainable Development Reserve (SDRTupé), Amazonas, Brazil.

\begin{tabular}{lccccc}
\hline Patch & Individuals & Families & Richness & $\begin{array}{c}\text { Rare } \\
\text { species }\end{array}$ & $\begin{array}{c}\text { Exclusive } \\
\text { species }\end{array}$ \\
\hline A & 1413 & 30 & 77 & 28 & 20 \\
\hline B & 1299 & 35 & 72 & 22 & 21 \\
\hline C & 1244 & 34 & 90 & 37 & 31 \\
\hline Total & 3956 & 40 & 140 & 51 & 72 \\
\hline
\end{tabular}


Table 2. Phytosociological parameters for the 10 species with highest IVI per patch of white-sand forest patches in the Tupé Sustainable Development Reserve (SDR Tupé), Amazonas (Brazil). N = number of individuals, RDe = Relative Density, RDo $=$ Relative Dominance, RFr = Relative Frequency, IVI = Importance Value Index. Values of RDe, RDo and RFr are in percentage.

\begin{tabular}{|c|c|c|c|c|c|c|}
\hline Species & Family & $\mathrm{N}$ & RDe & RDo & $\mathrm{RFr}$ & IVI \\
\hline \multicolumn{7}{|l|}{ Patch A } \\
\hline $\begin{array}{l}\text { Aspidosperma } \\
\text { aff. verruculosum }\end{array}$ & Apocynaceae & 607 & 42.96 & 32.76 & 2.34 & 78.04 \\
\hline $\begin{array}{l}\text { Aldina } \\
\text { heterophylla }\end{array}$ & Fabaceae & 72 & 5.10 & 20.59 & 2.33 & 28.02 \\
\hline $\begin{array}{l}\text { Simaba } \\
\text { guianensis }\end{array}$ & Simaroubaceae & 55 & 3.89 & 6.17 & 2.33 & 12.39 \\
\hline Parkia igneiflora & Fabaceae & 54 & 3.82 & 3.21 & 2.33 & 9.36 \\
\hline $\begin{array}{l}\text { Conceveiba } \\
\text { terminalis }\end{array}$ & Euphorbiaceae & 34 & 2.41 & 5 & 1.55 & 8.95 \\
\hline $\begin{array}{l}\text { Macrolobium } \\
\text { arenarium }\end{array}$ & Fabaceae & 34 & 2.41 & 3.26 & 1.55 & 7.22 \\
\hline Clusia nemorosa & Clusiaceae & 53 & 3.75 & 1.11 & 2.33 & 7.19 \\
\hline $\begin{array}{l}\text { Dimorphandra } \\
\text { vernicosa }\end{array}$ & Fabaceae & 30 & 2.12 & 2.65 & 2.33 & 7.10 \\
\hline Byrsonima laevis & Malphiguiaceae & 29 & 2.05 & 1.23 & 2.33 & 5.60 \\
\hline $\begin{array}{l}\text { Pradosia } \\
\text { schomburgkiana }\end{array}$ & Sapotaceae & 24 & 1.70 & 0.73 & 2.33 & 4.75 \\
\hline \multicolumn{7}{|l|}{ Patch B } \\
\hline $\begin{array}{l}\text { Aldina } \\
\text { heterophylla }\end{array}$ & Fabaceae & 80 & 6.16 & 37.12 & 2.27 & 45.55 \\
\hline $\begin{array}{l}\text { Aspidosperma } \\
\text { aff. verruculosum }\end{array}$ & Apocynaceae & 133 & 10.24 & 10.01 & 2.27 & 22.52 \\
\hline Pagamea duckei & Rubiaceae & 173 & 13.32 & 2.82 & 2.27 & 18.41 \\
\hline $\begin{array}{l}\text { Manilkara } \\
\text { bidentata }\end{array}$ & Sapotaceae & 92 & 7.08 & 8.74 & 2.27 & 18.10 \\
\hline Licania lata & Chrysobalanaceae & 109 & 8.39 & 5.04 & 2.27 & 15.70 \\
\hline $\begin{array}{l}\text { Clusia aff. } \\
\text { spathulaefolia }\end{array}$ & Clusiaceae & 99 & 7.62 & 2.24 & 2.27 & 12.13 \\
\hline $\begin{array}{l}\text { Mauritiella } \\
\text { armata }\end{array}$ & Arecaceae & 41 & 3.16 & 4.95 & 1.52 & 9.62 \\
\hline $\begin{array}{l}\text { Pradosia } \\
\text { schomburgkiana }\end{array}$ & Sapotaceae & 44 & 3.39 & 2.15 & 2.27 & 7.78 \\
\hline Clusia nemorosa & Clusiaceae & 59 & 4.54 & 0.90 & 2.27 & 7.72 \\
\hline $\begin{array}{l}\text { Humiria } \\
\text { balsamifera }\end{array}$ & Humiriaceae & 8 & 0.62 & 4.18 & 2.27 & 7.06 \\
\hline \multicolumn{7}{|l|}{ Patch C } \\
\hline $\begin{array}{l}\text { Protium } \\
\text { paniculatum }\end{array}$ & Burseraceae & 317 & 25.48 & 14.24 & 1.73 & 41.46 \\
\hline $\begin{array}{l}\text { Aldina } \\
\text { heterophylla }\end{array}$ & Fabaceae & 18 & 1.45 & 25.66 & 1.73 & 28.85 \\
\hline $\begin{array}{l}\text { Conceveiba } \\
\text { terminalis }\end{array}$ & Euphorbiaceae & 30 & 2.41 & 5.62 & 1.73 & 9.76 \\
\hline $\begin{array}{l}\text { Kutchubaea } \\
\text { sericantha }\end{array}$ & Rubiaceae & 69 & 5.55 & 2.25 & 1.73 & 9.53 \\
\hline $\begin{array}{l}\text { Swartzia } \\
\text { tessmannii }\end{array}$ & Fabaceae & 54 & 4.34 & 2.76 & 1.73 & 8.83 \\
\hline $\begin{array}{l}\text { Pouteria aff. } \\
\text { elegans }\end{array}$ & Sapotaceae & 50 & 4.02 & 2.91 & 1.73 & 8.66 \\
\hline Vitex triflora & Verbenaceae & 38 & 3.05 & 3.82 & 1.73 & 8.60 \\
\hline $\begin{array}{l}\text { Simaba } \\
\text { guianensis }\end{array}$ & Simaroubaceae & 36 & 2.89 & 3.77 & 1.73 & 8.40 \\
\hline $\begin{array}{l}\text { Simarouba } \\
\text { amara }\end{array}$ & Simaroubaceae & 21 & 1.69 & 3.56 & 1.73 & 6.98 \\
\hline $\begin{array}{l}\text { Aniba } \\
\text { santalodora }\end{array}$ & Lauraceae & 24 & 1.93 & 2.74 & 1.73 & 6.40 \\
\hline
\end{tabular}

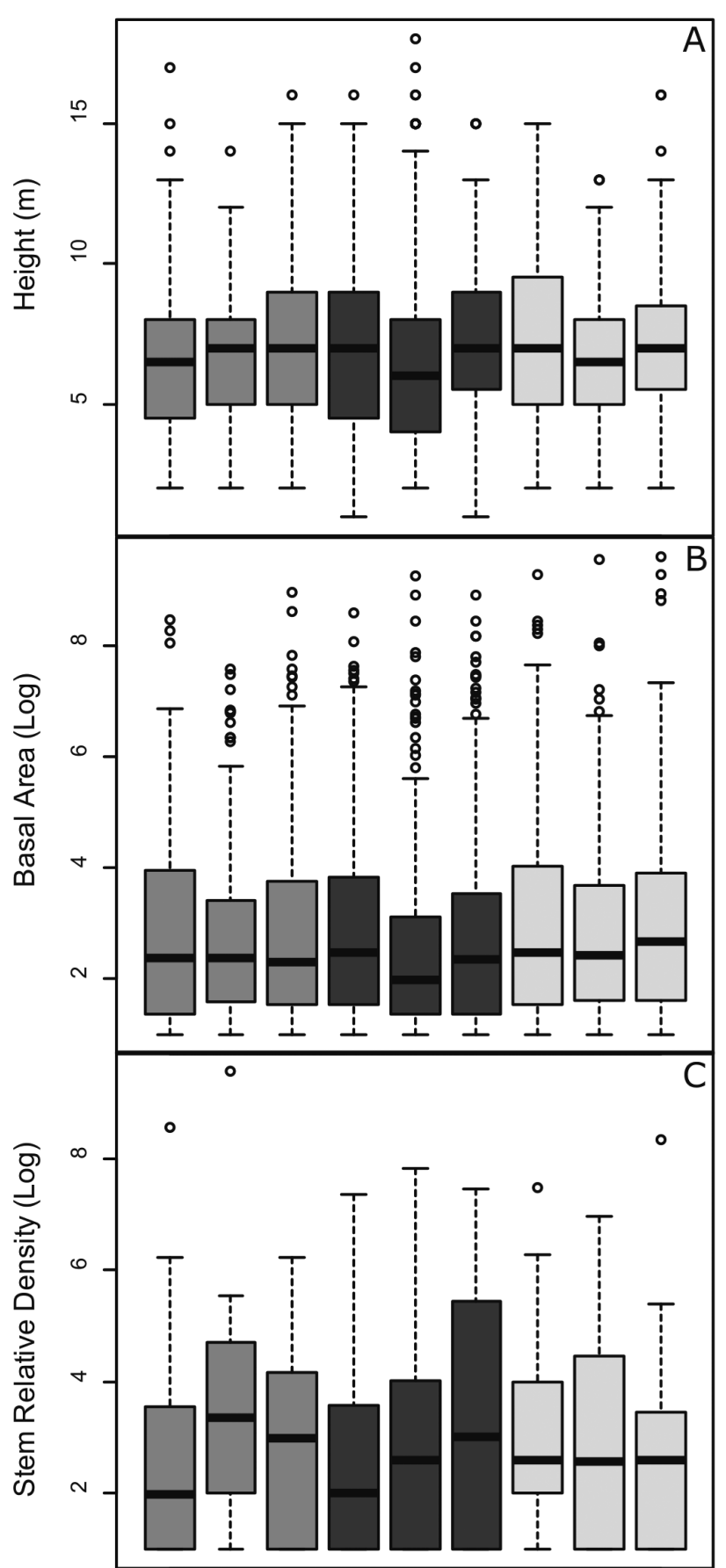

Patch A Patch B Patch C

Figure 2. Comparison of forest structure parameters (tree height, $A$; basal area, $B$; and relative density, $C$ ) among nine sampling plots in three white-sand vegetation patches in the Tupé Sustainable Development Reserve (SDR Tupé), Amazonas, Brazil. The box indicates the 25th and 75th percentiles, the line inside the box represents the median, the capped bars indicate the 10th and 90th percentiles, and the circles represent the extreme values. Different grey tones group plots belonging to each of the three forest patches. This figure is in color in the electronic version. 


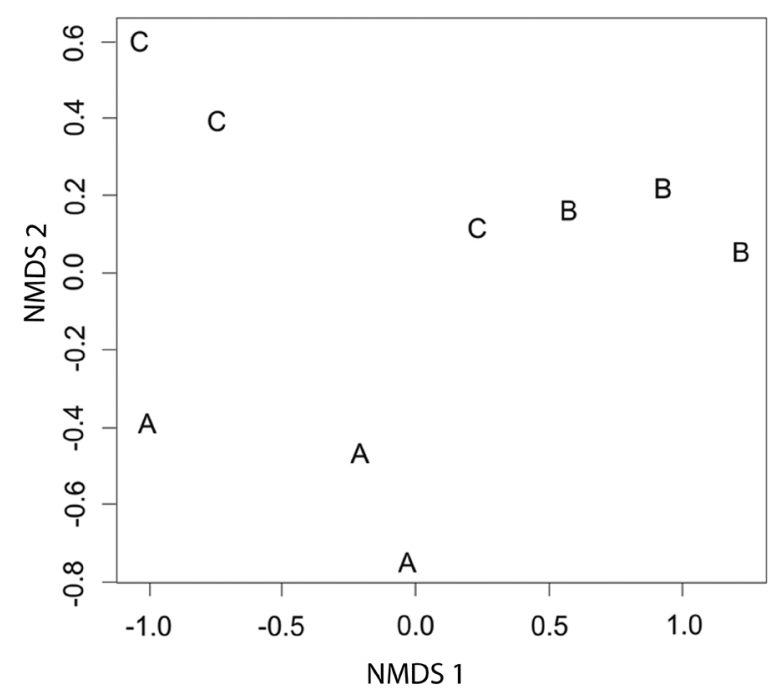

Figure 3. NMDS ordination diagram of the nine sampling plots in three white-sand forest patches in the Tupé Sustainable Development Reserve (SDRTupé), Amazonas (Brazil) based on species occurrence of trees with $\mathrm{DBH} \geq 5 \mathrm{~cm}$.

\section{Vegetation variation and soil fertility}

The three patches were characterized by sand predominance and nutrient-poor soils (Table 3). The single NMDS axis $(\mathrm{k}=1)$ explained $58.8 \%$ of the variation in species composition. The GLMM using this NMDS axis as dependent variable and soil parameters as independent variables explained $60.50 \%$ of the variation in species composition $\left(\mathrm{NMDS}=-1.165^{-17}+1.286^{-1}\right.$ $\mathrm{QM}-2.489^{-2} \mathrm{PS}-4.083^{-1} \mathrm{SB} ; \chi^{2}=9.7086 ; \mathrm{R}^{2}=0.6050 ; \mathrm{P}$ $=0.02)$, yet only the variable sum of bases $(\mathrm{SB})$ contributed significantly to the model $(\mathrm{t}=-3.094 ; \mathrm{P}=0.03)$ (Table 4). However, there was no significant effect of soil parameters on species richness and structural variation.

Some species were widely distributed along the fertility gradient, while others were restricted to parts of it. Species such as Ocotea amazonica (Meisn.) Mez and Pouteria oblanceolata Pires were strongly associated with localities with the lowest fertility, while Mauritiella armata (Mart.) Burret and Protium heptaphyllum (Aubl.) Marchand were more frequently found in plots with the greatest fertility (Figure 4).

Table 3. Soil parameter values for three white-sand forest patches (A, B and C) in the Tupé Sustainable Development Reserve (SDR Tupé), Amazonas (Brazil) and for other WSV areas in other studies. Values are the mean \pm standard deviation [except ${ }^{*}=$ variation coefficient $(\%)$ ].

\begin{tabular}{|c|c|c|c|c|c|}
\hline Soil variables & Patch A & Patch B & Patch C & Damasco et al. 2013 & Targhetta et al. 2015 \\
\hline \multicolumn{6}{|l|}{ Granulometric variables } \\
\hline Coarse Sand (\%) & $69.40 \pm 9.20$ & $69.31 \pm 9.20$ & $75.46 \pm 3.42$ & - & - \\
\hline Fine Sand (\%) & $25.91 \pm 8.47$ & $25.87 \pm 8.70$ & $21.41 \pm 3.28$ & - & - \\
\hline Total Sand (\%) & $95.31 \pm 0.72$ & $95.20 \pm 0.94$ & $96.87 \pm 0.20$ & $70.30 \pm 20^{*}$ & $93.40 \pm 1.50$ \\
\hline Silt (\%) & $1.99 \pm 1.09$ & $3.03 \pm 0.77$ & $1.67 \pm 0.46$ & $17.90 \pm 30^{*}$ & $4.80 \pm 0.80$ \\
\hline Clay (\%) & $2.68 \pm 0.37$ & $1.76 \pm 0.34$ & $1.45 \pm 0.26$ & $11.80 \pm 96^{*}$ & $1.80 \pm 1$ \\
\hline \multicolumn{6}{|l|}{ Edaphic variables } \\
\hline $\mathrm{pH}\left(\mathrm{H}_{2} \mathrm{O}\right)$ & $4.29 \pm 0.04$ & $4.21 \pm 0.07$ & $4.27 \pm 0.11$ & $4.50 \pm 4^{*}$ & $4.27 \pm 0.32$ \\
\hline$C(g / k g)$ & $8.64 \pm 1.47$ & $10.05 \pm 2.58$ & $6.59 \pm 0.94$ & - & $1.20 \pm 0.20$ \\
\hline $\mathrm{OM}(\mathrm{g} / \mathrm{kg})$ & $14.87 \pm 2.54$ & $17.29 \pm 4.44$ & $11.34 \pm 1.61$ & - & - \\
\hline$P\left(\mathrm{mg} / \mathrm{dm}^{3}\right)$ & $2.33 \pm 0.57$ & $2.66 \pm 0.57$ & $2 \pm 0$ & $10.90 \pm 94^{*}$ & $4.70 \pm 1.80$ \\
\hline $\mathrm{K}\left(\mathrm{mg} / \mathrm{dm}^{3}\right)$ & $16.33 \pm 2.88$ & $16.66 \pm 3.21$ & $10 \pm 1$ & $26.70 \pm 72^{*}$ & $13.30 \pm 3.50$ \\
\hline $\mathrm{Na}\left(\mathrm{mg} / \mathrm{dm}^{3}\right)$ & $3.66 \pm 2.08$ & $7.33 \pm 1.15$ & $4.66 \pm 1.52$ & - & - \\
\hline $\mathrm{Ca}\left(\mathrm{cmolc} / \mathrm{dm}^{3}\right)$ & $0.06 \pm 0.02$ & $0.04 \pm 0.02$ & $0.04 \pm 0$ & $0.14 \pm 79^{*}$ & $0.03 \pm 0.01$ \\
\hline $\mathrm{Mg}\left(\mathrm{cmolc} / \mathrm{dm}^{3}\right)$ & $0.13 \pm 0.05$ & $0.11 \pm 0.02$ & $0.07 \pm 0$ & $0.10 \pm 50^{*}$ & $0.06 \pm 0.01$ \\
\hline $\mathrm{Al}\left(\mathrm{cmolc} / \mathrm{dm}^{3}\right)$ & $0.68 \pm 0.13$ & $0.81 \pm 0.20$ & $0.61 \pm 0.10$ & $0.58 \pm 76^{*}$ & $0.80 \pm 0.20$ \\
\hline $\mathrm{H}+\mathrm{Al}\left(\mathrm{cmolc} / \mathrm{dm}^{3}\right)$ & $4.21 \pm 0.29$ & $4.44 \pm 1.21$ & $3.20 \pm 0.33$ & - & - \\
\hline $\mathrm{SB}\left(\mathrm{cmolc} / \mathrm{dm}^{3}\right)$ & $0.25 \pm 0.07$ & $0.23 \pm 0.04$ & $0.15 \pm 0$ & - & $0.15 \pm 0.02$ \\
\hline CTC (t) (cmolc/dm $\left.{ }^{3}\right)$ & $0.93 \pm 0.12$ & $1.04 \pm 0.25$ & $0.77 \pm 0.10$ & - & - \\
\hline CTC (T) (cmolc/dm $\left.{ }^{3}\right)$ & $4.46 \pm 0.34$ & $4.68 \pm 1.26$ & $3.35 \pm 0.32$ & - & - \\
\hline V (\%) & $5.59 \pm 1.39$ & $5.06 \pm 0.41$ & $4.67 \pm 0.54$ & - & - \\
\hline m (\%) & $72.86 \pm 8.36$ & $77.52 \pm 1.12$ & $79.55 \pm 3.01$ & - & - \\
\hline $\mathrm{Fe}\left(\mathrm{mg} / \mathrm{dm}^{3}\right)$ & $3.66 \pm 0.57$ & $5.33 \pm 1.52$ & $3 \pm 0$ & $78.20 \pm 98^{*}$ & $13.50 \pm 9.50$ \\
\hline $\mathrm{Zn}\left(\mathrm{mg} / \mathrm{dm}^{3}\right)$ & $0.41 \pm 0.12$ & $0.35 \pm 0.07$ & $0.33 \pm 0.04$ & $0.29 \pm 116^{*}$ & $0.20 \pm 0.10$ \\
\hline $\mathrm{Mn}\left(\mathrm{mg} / \mathrm{dm}^{3}\right)$ & $0.92 \pm 0.67$ & $0.89 \pm 0.75$ & $1.27 \pm 0.49$ & $1.50 \pm 186^{*}$ & $0.50 \pm 0.10$ \\
\hline $\mathrm{Cu}\left(\mathrm{mg} / \mathrm{dm}^{3}\right)$ & $0.11 \pm 0$ & $0.09 \pm 0.01$ & $0.08 \pm 0.01$ & - & $0.07 \pm 0.01$ \\
\hline
\end{tabular}

C (organic carbon), OM (organic matter), pH in water (proportion 1:2,5), H+AL (potential acidity), SB (sum of bases), CTC(t) (effective cation exchange capacity), $\mathrm{CTC}(\mathrm{T})$ (cation exchange capacity under neutral $\mathrm{pH}), \mathrm{V}$ (saturation index for bases), $\mathrm{m}$ (saturation index for aluminum). 
ACTA

AMAZONICA

DEMARCHI et al. Soil-vegetation relations in white-sand vegetation

Table 4. Effects of edaphic variables on tree species composition in three white-sand forest patches in the Tupé Sustainable Development Reserve (SDRTupé), Amazonas (Brazil). Estimate $=\beta$ value of analyzed fixed variables; Std. Error $=$ standard error; $t$ value $=t$-test value; $P$ value: probability value.

\begin{tabular}{|c|c|c|c|c|}
\hline Fixed Effects & Estimate & Std. Error & t value & Pvalue \\
\hline Intercept & $-1.165^{-17}$ & $1.059^{-1}$ & - & - \\
\hline $\mathrm{Mn}^{2+}$ & $1.286^{-1}$ & $1.255^{-1}$ & 1.025 & 0.36 \\
\hline Silt & $-2.489^{-2}$ & $1.247^{-1}$ & -0.200 & 0.82 \\
\hline Sum of Bases (SB) & $-4.083^{-1}$ & $1.320^{-1}$ & -3.094 & $0.03^{*}$ \\
\hline
\end{tabular}

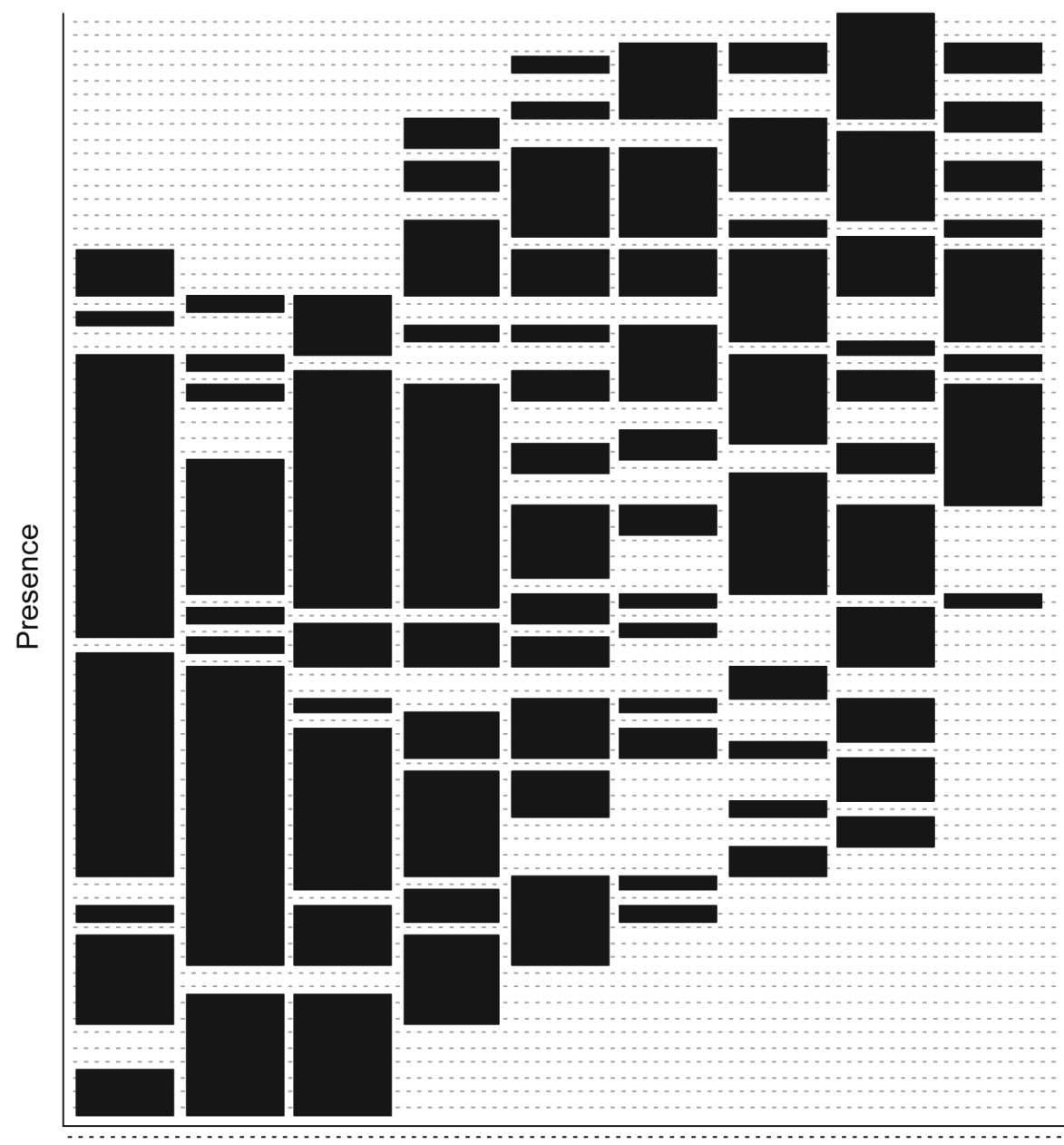

Protumsp.

Clusia renggerioides

Protum heptaphyllum

Mauritellia armata

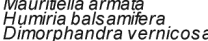

Roucheria columbiana

Clusia aff spathulaefolia

Aspidosperma aff.verruculosum

Licania lata afflaevis

Protium aff soruceanum

rattinnickia burseritolia

Clusirn

Clusia nemorosa

Ormosiacosstulata
Ficus greitiana

Tovomita ac autfifora

Tovomita acutiflora
Macrolobium arenarium

Ouratea Spruceana
Adina heterophylla

Byrsonima laevis

uapirasp.

Pagamea ducke

Matayba opaca

Parkia igneiffora

Conceveiba terminalis

Vitex trifora

Lacmellea arborescens

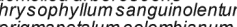

Sterigmapetalum colombianu

Macoubea sprucei
Ocotea aciphylla

colea aciphy

Inga laterifior

Brosimumguianense

Ocotea sp. 1 .

Kutchubaea serica
Simaroubath

Schemflera umbrosa

Mic ani a argyrophylla
Tainira gulanensis

Pouteria s. 1

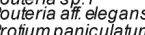

Protumpaniculatum
Endlicheria arenosa

Eospyros sp.
Dosa

.

iscophora guianensis

Dulacia candida

Duroia saccifera
Hebepetalum humiritollium

Cybiantrus guy anensis

Cylopia barbata

Chrysophyllum cuneifolium

Licaria sp. 1

Hirtella hispidula

Schefflera decaphylla

Pouteria oblancelolata

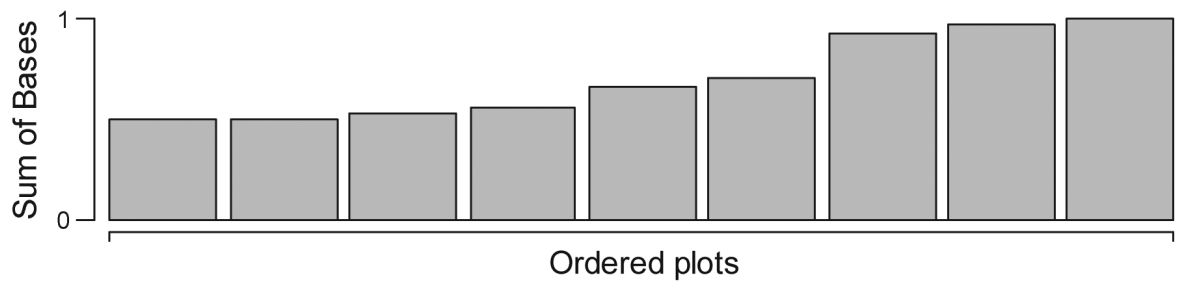

Figure 4. Species ordination along the soil fertility gradient represented by the sum of bases SB content of the nine sampling plots in three white-sand forest patches in the Tupé Sustainable Development Reserve (SDR Tupé), Amazonas, Brazil. Only species that had five or more recorded individuals with DBH $\geq 5 \mathrm{~cm}$ were included. 


\section{DISCUSSION}

Our results show that, although the floristic composition and basal area differed significantly between patches and the height differed significantly among plots, only the variation in species composition was related to soil parameters. This soil effect on species composition may explain why the most important species (IVI) varied among relatively nearby patches.

Fabaceae, followed by Sapotaceae, were the families with the highest species richness, which agrees with previous studies in other WSV areas in the Amazon (Anderson 1981; Coomes and Grubb 1996; Ferreira 2009; Fine et al. 2010; Stropp et al. 2011; Damasco et al. 2013; Targhetta et al. 2015; Guevara et al. 2016). Apocynaceae and Burseraceae are also important, mainly due to the high abundance of Aspidosperma aff. verruculosum and Protium paniculatum var. modestum Daly, respectively. Lauraceae, Moraceae and Myrtaceae had high richness, but low abundance in the study patches. Common families in other Amazonian forests, such as Lecythidaceae and Myristicaceae (Gentry 1988), were poorly represented in the white-sand forest patches in SDR Tupé.

The greatest height and DBH values achieved by Aldina heterophylla exemplify the important ecological role of this species in WSV, as was also found in other studies (Anderson et al. 1975; Stropp et al. 2011; Targhetta et al. 2015). The smaller size of the majority of species when compared to other dominant forest formations in Amazonia, such as terra-firme and seasonal flooded forests, justifies the adoption of the individual inclusion criteria of $\mathrm{DBH} \geq 5 \mathrm{~cm}$. If the inclusion criteria commonly used in Amazon forests of DBH $\geq 10 \mathrm{~cm}$ had been adopted, 60\% of the individuals in our sampling plots, including abundant species such as Pagamea duckei Standl., would not have been sampled.

Patches had significantly different floristic composition, but plots in the same patch tended to have similar species composition. Previous studies have related differences in floristic composition to factors such as the insular characteristics of WSV (Anderson 1981; Prance 1996), the dispersion capacity limited to anemochory and ornithochory (Macedo and Prance 1978), the effect of fire (Vicentini 2004; Adeney et al. 2016), past anthropogenic actions (Prance and Schubart 1978) and differences in abiotic characteristics among patches (Tiessen $e t$ al. 1994; Damasco et al. 2013; Adeney et al. 2016).

The dominance of just a few species, as found in this study, is common in WSV; the sum of the 10 most abundant species often exceeds $50 \%$ of all individuals (Boubli 2002; Fine et al. 2010; Stropp et al. 2011). This pattern also occurs in other Amazonian forest formations (Pitman et al. 2001; ter Steege et al. 2013). Only one species was among the 10 most dominant species in all patches, and only three were among the 10 most dominant species in at least two of the sampled patches. This disagrees with Fine et al. (2010) who, on a regional scale, proposed that dominant species in an area of WSV tend also to be dominant in other nearby WSV areas. However, the reduced spatial scale and the limited number of sampling units in our study preclude any further extrapolations.

Variations in edaphic characteristics change significantly the distribution and abundance of woody species in local environments (Comes and Grubb 1996; Clark et al. 1998; Tuomisto et al. 2003; John et al. 2007), and our results showed that this effect occurs even among nearby white-sand forest patches, and should be investigated in more detail.

The sum of bases SB was the only parameter strongly linked to floristic composition. SB is a good indicator of soil fertility and was closely related to floristic composition in oligotrophic ecosystems (Assis et al. 2011). In other vegetation types on less oligotrophic soils, SB was also the best predictor of species composition (Ruggiero et al. 2002; Zuquim et al. 2014). SB is composed of macronutrients that influence directly the basic processes of plants, such as hydration regulation, stomatal movement and photosynthesis, having an essential role in all stages of plant development (Larcher 2000). The presence and quantity of the elements that compose the $\mathrm{SB}$ are directly related to other soil parameters such as soil texture and variation in groundwater level. Although soil texture is not a physiologically important edaphic factor, elements such as silt and clay may increase water-holding and nutrient retention capacity (Mendonça et al. 2015). The continuous variation in groundwater level, intrinsically related to soil properties, leaches the soil components to lower layers (Franco and Dezzeo 1994). Thus, the interaction between texture and groundwater level is essential to predict soil fertility and species composition (Targhetta et al. 2015).

The variation in SB was significantly related to species composition, but it was not related to species richness nor vegetation structure. In the WSV of Viruá National Park, soil fertility directly influenced the vegetation structure in different phytophysiognomies and may counterbalance the negative effects of flooding (Damasco et al. 2013). In our study soil fertility in white-sand forest patches was less variable than in Viruá NP, but was nevertheless enough to influence floristic composition.

This lack of relation between soil fertility and vegetation structure may reflect the need for plants growing in oligotrophic environments to allocate much of their energy to form secondary compounds for defending themselves against herbivory, in detriment of both growth in height and diameter (Jansen 1974; Fine et al. 2006). It also suggests that other factors rather than soil may be involved in structuring the vegetation.

A significant change in species composition related to small changes in soil parameters is compatible with the extreme condition experienced by WSV. In addition to the extreme nutrient poverty of the soil, seasonal hydric saturation can act as an additional filter, selecting species capable of surviving periods of soil anoxia (Parolin and Wittmann 2010; Piedade $e t$ al. 2013). In contrast, periods of moisture loss accentuated by 
high light penetration, high porosity and low water retention capacity of sandy soils, can subject WSV to physiological constraints during the dry season, when effective drought conditions prevail (Franco and Dezzeo 1994; Vicentini 2004).

Our results highlight the role of edaphic variations in promoting species composition heterogeneity in white-sand forest patches. In this extremely nutrient-poor ecosystem, any nutrient addition may change the habitat partitioning of component species, and therefore may cause changes in species distribution and assemblage composition (Grubb 1977; Oliveira et al. 2014). The differentiation of species composition based on minor resource variations may be an important mechanism for niche differentiation in plant communities.

\section{CONCLUSIONS}

We detected significant differences among white-sand forest patches located at about $4 \mathrm{~km}$ from each other in an area in the central Brazilian Amazon. Sampling plots within patches tended to have similar species composition. We also found that small differences in soil parameters explained species composition heterogeneity in the white-sand forest patches, reflected in the large number of species $(51.4 \%)$ that were exclusive to only one patch. Changes in the sum of bases were likely to be linked to species composition variation. Although these changes do not necessarily influence species richness and other structural parameters, they may be related to differential responses of a species abundance, or whether it is present or absent from a white-sand area.

\section{ACKNOWLEDGEMENTS}

We thank the Coordenaçâo de Aperfeiçoamento de Pessoal de Nível Superior - CAPES for the first author's scholarship, Aline Lopes received scholarship from the Programa de Apoio à Fixação de Doutores no Amazonas - FIXAM/AM. We also would like to thank the Fundaçáo de Amparo à Pesquisa do Estado do Amazonas - FAPEAM (public call: 021/2011) and Conselho Nacional de Desenvolvimento Científico e Tecnológico - CNPq/PELD-MAUA (grant number: 403792/2012-6) for financing the research, as well as Instituto Nacional de Pesquisas da Amazônia -INPA and MAUA-INPA technicians for all the support. Special thanks to the SDR Tupé dwellers for the hospitality, Affonso Henrique, Bruno Cintra, Paula Guarido, Álvaro Bastos, Diego Ken, José Ferreira, Marco Volpato and David Marical for helping in the field, Antônio Mello, José Ramos, Mario Terra, Fátima Melo, Alberto Vicentini, André Correa, and Jhennyffer Alves for helping to identify the plants, and Maria Julia Ferreira for editing the figures.

\section{REFERENCES}

Adeney, J.M.; Christensen, N.L.; Vicentini, A.; Cohn-Haft, M. 2016. White-sand Ecosystems in Amazonia. Biotropica, 48: 7-23.
Anderson, A.B.; Prance, G.T.; Albuquerque, B.W.P. 1975. Estudos sobre as vegetaçóes de Campinas Amazônica III: a vegetação lenhosa da Campina da Reserva Biológica INPA-SUFRAMA (Manaus-Caracaraí, km 62). Acta Amazonica, 5: 225-246.

Anderson, A.B. 1981. White-sand vegetation of Brazilian Amazonia. Biotropica, 13: 199-210.

APG IV. 2016. An update of the Angiosperm Phylogeny Group classification for the orders and families of flowering plants: APG IV. Botanical Journal of the Linnean Society, 181: 1-20.

Assis, M.A.; Prata, E.M.B.; Pedroni, F.; Sanchez, M.; Eisenlohr, P.V.; Martins, F.R.; et al. 2011. Florestas de restinga e de terras baixas na planície costeira do sudeste do Brasil: vegetação e heterogeneidade ambiental. Biota Neotropica, 11: 103-121.

Borcard, D.; Gillet, F.; Legendre, P. 2011. Numerical Ecology with $R$. Springer, New York, 306p.

Boubli, J.P. 2002. Lowland floristic assessment of Pico da Neblina National Park, Brazil. Plant Ecology, 160: 149-167.

Braga, P.I.S. 1979. Subdivisão fitogeográfica, tipos de vegetação, conservação e inventário florístico da Floresta Amazônica. Acta Amazonica, 9: 53-80.

Bongers, F.; Engelen, D.; Klinge, H. 1985. Phytomass structure of natural plant communities on spodosols in southern Venezuela: the Bana woodland. Vegetatio, 63: 13-34.

Clark, D.B.; Clark, D.A.; Read, J. 1998. Edaphic variation and the mesoscale distribution of tree species in a neotropical rain forest. Journal of Ecology, 86: 101-112.

Coomes, D.A.; Grubb, P.J. 1996. Amazonian caatinga and related communities at La Esmeralda, Venezuela: forest structure, physiognomy and floristics, and control by soil factors. Vegetatio, 122: 167-191.

Coomes, D.A. 1997. Nutrient status of Amazonian caatinga forests in a seasonally dry area: nutrient fluxes in litter fall and analyses of soils. Canadian Journal of Forest Research, 27: 831-839.

Coronado, E.N.H.; Baker, T.R.; Phillips, O.L.; Pitman, N.C.A.; Pennington, R.T.; Martínez, R.V.; et al. 2009. Multi-scale comparisons of tree composition in Amazonian Terra Firme Forests. Biogeosciences, 6: 2719-2731.

Curtis, J.T.; McIntosh, R.P. 1951. An upland forest continuum in the prairie-forest border region of Wisconsin. Ecology, 32: 476-496.

Damasco, G.; Vicentini, A.; Castilho, C.V.; Pimentel, T.P.; Nascimento, H.E.M. 2013. Disentangling the role of edaphic variability, flooding regime and topography of Amazonian white-sand vegetation. Journal of Vegetation Science, 24: 384-394.

Embrapa. 1997. Manual de Métodos de Análise de Solos. 2da ed., Centro Nacional de Pesquisa de Solos, Rio de Janeiro, 212p.

Ferreira, C.A.C. 2009. Análise comparativa de vegetação lenhosa do ecossistema campina na Amazônia brasileira. PhD thesis, Instituto Nacional de Pesquisas da Amazônia, Universidade Federal do Amazonas, Manaus, Brazil, 277p.

Fine, L.V.; Miller, Z.J.; Mesones, I.; Irazuzta, S.; Appel, H.M.; Stevens, M.H.H.; et al. 2006. The growth-defense trade-off and habitat specialization by plants in Amazonian forests. Ecology, 87: 150-162. 
Fine, P.V.A.; García-Villacorta, R.; Pitman, N.C.A.; Mesones, I.; Kembel, S.W. 2010. A floristic study of the White-sand forests of Peru. Annals of the Missouri Botanical Garden, 97: 283-305.

Fine, P.V.A.; Baraloto, C. 2016. Habitat Endemism in White-sand Forests: Insights into the Mechanisms of Lineage Diversification and Community Assembly of the Neotropical Flora. Biotropica, 48: 24-33.

Franco, W.; Dezzeo, N. 1994. Soils and soil-water regime in the terra-firme-caatinga forest complex near San Carlos de Rio Negro, state of Amazonas, Venezuela. Interciencia, 19: 305-316.

Gentry, A.H. 1988. Changes in plant community diversity and floristic composition on enviromental and geographical gradients. Annals of the Missouri Botanical Garden, 75: 1-34.

Grubb, P.J. 1977. The Maintenance of Species-richness in Plant Communities: The Importance of the Regeneration Niche. Biological Reviews, 52: 107-145.

Guevara, J.E.; Damasco, G.; Baraloto, C.; Fine, P.V.A.; Peñuela, M.C.; Castilho, C. et al. 2016. Low Phylogenetic Beta Diversity and Geographic Neo-endemism in Amazonian White-sand Forests. Biotropica, 48: 34-46.

Heyligers, P.C. 1963. Vegetation and soil of a White-Sand Savanna in Suriname. Mededelingen van het Botanisch Museum en Herbarium van de Rijksuniversiteit te Utrecht, 191: 1-148.

Hubbell, S.P.; He, F.; Condit, R.; Borda-de-Água, L.; Kellner, J.; ter Steege, H. 2008. How many tree species are there in the Amazon and how many of them will go extinct? Proceedings of the National Academy of Sciences, 105: 11498-11504.

IBGE. 2012. Manual Técnico da Vegetação brasileira. 2 da ed., Instituto Brasileiro de Geografia e Estatística, Rio de Janeiro, 275p.

Janzen, D. 1974. Tropical blackwater rivers, animals and mast fruiting by Dipterocarpaceae. Biotropica, 6: 69-103.

John, R.; Dalling, J.W.; Harms, K.E.; Yavitt, J.B.; Stallard, R.F.; Mirabello, M.; et al. 2007. Soil nutrients influence spatial distributions of tropical tree species. Proceedings of the National Academy of Sciences, 104: 864-869.

Junk, W.J.; Piedade, M.T.F.; Schöngart, J.; Cohn-Haft, M.; Adeney, J.M.; Wittmann, F. 2011. A classification of major naturallyoccurring Amazonian lowland wetlands. Wetlands, 31: 623:640.

Kubitzki, K. 1989a. The ecogeographical differentiation of Amazon inundation forests. Plant Systematics and Evolution, 162: 285-304.

Kubitzki, K. 1989b. Amazon lowland and Guayana highland historical and ecological aspects of the development of their floras. Amazoniana, 11: 1-12.

Larcher, W. 2000. Ecofisiologia vegetal. RiMa Artes e Textos, São Carlos, 531p.

Luizão, F.J.; Luizão, R.C.C.; Proctor, J. 2007. Soil acidity and nutrient deficiency in central Amazonian heath forest soils. Plant Ecology, 192: 209-224.

Macedo, M.; Prance, G.T. 1978. Notes on the vegetation of Amazonia II. The dispersal of plants in Amazonian white sand campinas: The campinas as functional islands. Brittonia, 30: 203-215.

Magnusson, W.E; Mourão, G. 2005. Estatística sem Matemática. 2da ed., Publisher Planta, Londrina, 138p.
Mendonça, B.A.F.; Filho, E.I.F.; Schaefer, C.E.G.R.; Simas, F.N.B.; Paula, M.D. 2015. Os solos das Campinaranas na Amazônia Brasileira: Ecossistemas arenícolas oligotróficos. Ciência Florestal, 25: 827-839.

Oksanen, J.F.; Blanchet, G.; Kindt, R.; Legendre, P.; Minchin, P.R.; O’Hara, R.B.; et al. 2013. vegan: Community Ecology Package, R package version 2.0-7. (http://CRAN.R-project.org/ package=vegan).

Oliveira, A.A.; Vicentini, A.; Chave, J.; Castanho, C.T.; Davies, S.J.; Martini, A.M.Z. et al. 2014. Habitat specialization and phylogenetic structure of tree species in a coastal Brazilian whitesand forest. Journal of Plant Ecology, 7:134-144.

Parolin, P.; Wittmann, F. 2010. Struggle in the flood: tree responses to flooding stress in four tropical floodplain systems. AoB Plants, v2010: plq003.

Piedade, M.T.F.; Schöngart, J.; Wittmann, F.; Parolin, P.; Junk, W.J. 2013. Impactos da inundação e seca na vegetação de áreas alagáveis amazônicas. In: Borma, L.S.; Nobre, C.A. (Org.). Secas na Amazônia: causas e consequências. São Paulo, Oficina de Textos, p.268-305.

Pires, J.M.; Prance, G.T. 1985. The vegetation types of the Brazilian Amazon. In: Prance, G.T.; Lovejoy, T.E. (Ed.). Key Enviroments: Amazonia. Oxford, Pergamon Press, p.109-145.

Pitman, N.C.A.; Terborgh, J.W.; Silman, M.R.; Núñez, P.V.; Neill, D.A.; Cerón, C.E.; et al. 2001. Dominance and distribution of tree species in upper Amazonian Terra Firme forests. Ecology, 82: 2101-2117.

Prance, G.T.; Schubart, H.O.R. 1978. Nota preliminar sobre a origem das campinas abertas de areia branca do rio Negro. Acta Amazonica, 3: 567-570.

Prance, G.T.; Daly, D. 1989. Brasilian Amazon. In: Campbell, D.G.; Hammond, H.D. (Ed.). Floristic inventory of tropical countries. New York Botanical Garden, New York, p.523-533.

Prance, G.T. 1996. Islands in Amazonia. Philosophical Transactions of the Royal Society of London. Series B, 351: 823-833.

R Core Team. 2014. R: A language and environment for statistical computing. R Foundation for Statistical Computing, Vienna, Austria. (http://www.R-project.org/).

Radam Brasil. 1978. Levantamento de recursos naturais. v.18. Folha SA. 20 Manaus, Departamento Nacional de Produção Mineral, Rio de Janeiro, 747p.

Reflora - Flora do Brasil 2020 em construção. Jardim Botânico do Rio de Janeiro. (http://floradobrasil.jbrj.gov.br/). Accessed on 22/05/2017.

Richardt, K.; Santos, A.; Nascimento-Filho, V.; Bacc, O.O.S. 1975. Movimento de água subterrânea em ecossistema Campina Amazônica. Acta Amazonica, 6: 229-290.

Ruggiero, P.G.C.; Batalha, M.A.; Pivello, V.R.; Meirelles, S.T. 2002. Soil-vegetation relationships in cerrado (Brazilian savanna) and semideciduous forest, Southeastern Brazil. Plant Ecology, 160: 1-16.

Scudeller, V.V.; Aprile, F.M.; Melo, S.; Santos-Silva, E.N. 2005. Reserva de Desenvolvimento Sustentável do Tupé: características gerais. In: Santos-Silva, E.N.; Aprile, F.M.; Scudeller, V.V.; Melo, S. (Org.). Biotupé: Meio físico, diversidade biológica e sociocultural 
do Baixo Rio Negro, Amazônia Central. Instituto Nacional de Pesquisas da Amazônia, Manaus, p. XI-XXI.

Shepherd, G.J. 2010. Fitopac - Manual do usuário. Departamento de Botânica, Universidade Estadual de Campinas, Campinas, Brazil, 91p.

Sobrado, M.A. 2009. Leaf tissue water relations and hydraulic properties of sclerophyllous vegetation on white sands of the upper Rio Negro in the Amazon region. Journal of Tropical Ecology, 25: 271-280.

Stropp, J.; Van Der Sleen, P.; Assunção, P.A.; Silva, A.L.; ter Steege, H. 2011. Tree communities of white-sand and terra-firme forests of the upper Rio Negro. Acta Amazonica, 41: 521-544.

Targhetta, N.; Kesselmeier, J.; Wittmann, F. 2015. Effects of the hydroedaphic gradient on tree species composition and aboveground wood biomass of oligotrophic forest ecosystems in the central Amazon basin. Folia Geobotanica, 50: 185-205.

ter Steege, H.; Pitman, N.C.A.; Sabatier, D.; Baraloto, C.; Salomão, R.P.; Guevara, J.E.; et al. 2013. Hyperdominance in the Amazonian Tree Flora. Science, 342: 325-336.

Tiessen, H.; Chacon, P.; Cuevas, E. 1994. Phosphorus and nitrogen status in soils and vegetation along a toposequence of dystrophic rainforests on the upper Rio Negro. Oecologia, 99: 145-150.

Tuomisto, H.; Ruokolainem, K.; Aguilar, M.; Sarmiento, A. 2003. Floristic patterns along a 43-km long transect in an Amazonian rain forest. Journal of Ecology, 91: 743-756.

Veloso, H.P.; Rangel Filho, A.L.R.; Lima, J.C.A. 1991. Classificação da vegetação brasileira, adaptada a um sistema universal. Instituto Brasileiro de Geografia e Estatística, Rio de Janeiro, 124p.

Vicentini, A. 2004. A vegetação ao longo de um gradiente edáfico no Parque Nacional do Jaú. In: Borges, S.H.; Iwanaga, S.; Durigan,
C.C.; Pinheiro, M.R. (Ed.). Janelas para a biodiversidade no Parque Nacional do Jaú: uma estratégia para o estudo da biodiversidade na Amazônia. Fundaçáo Vitória Amazônica, WWF, IBAMA, Manaus, p.117-143.

Zuquim, G.; Tuomisto, H.; Jones, M.M.; Prado, J.; Figueiredo, F.O.G.; Moulatlet, G.M.; et al. 2014. Predicting environmental gradients with fern species composition in Brazilian Amazonia. Journal of Vegetation Science, 25: 1195-1207.

RECEIVED: $30 / 12 / 2016$

ACCEPTED: 04/09/2017

ASSOCIATE EDITOR: Natália Ivanauskas

\section{SUPPLEMENTARY MATERIAL}

(only available in the electronic version)

DEMARCHI et al. Floristic composition, structure and soil-vegetation relations in three white-sand soil patches in central Amazonia.

Table S1. Correlation matrix of soil parameters collected in three white-sand vegetation patches in Tupé Sustainable Development Reserve, in the central Brazilian Amazon. (This table is available in electronic edition only).

Table S2. Phytosociological parameters of species found in the three areas of white-sand vegetation sampled in Tupé Sustainable Development Reserve, central Brazilian Amazon. N. = number of individuals, N Par = number of parcels in wich species occurred, $\mathrm{RDe}=$ Relative Density, $\mathrm{RDo}=$ Relative Dominance, $\mathrm{RFr}$ $=$ Relative Frequency, IVI = Importance Value Index. Voucher number refers to material deposited in the herbaria of Instituto Nacional de Pesquisas da Amazônia (INPA) and Instituto Federal do Amazonas (EAFM). (This table is available in electronic edition only). 
ORIGINAL ARTICLE

\section{SUPPLEMENTARY MATERIAL (only available in the electronic version)}

DEMARCHI et al. Floristic composition, structure and soil-vegetation relations in three white-sand soil patches in central Amazonia.

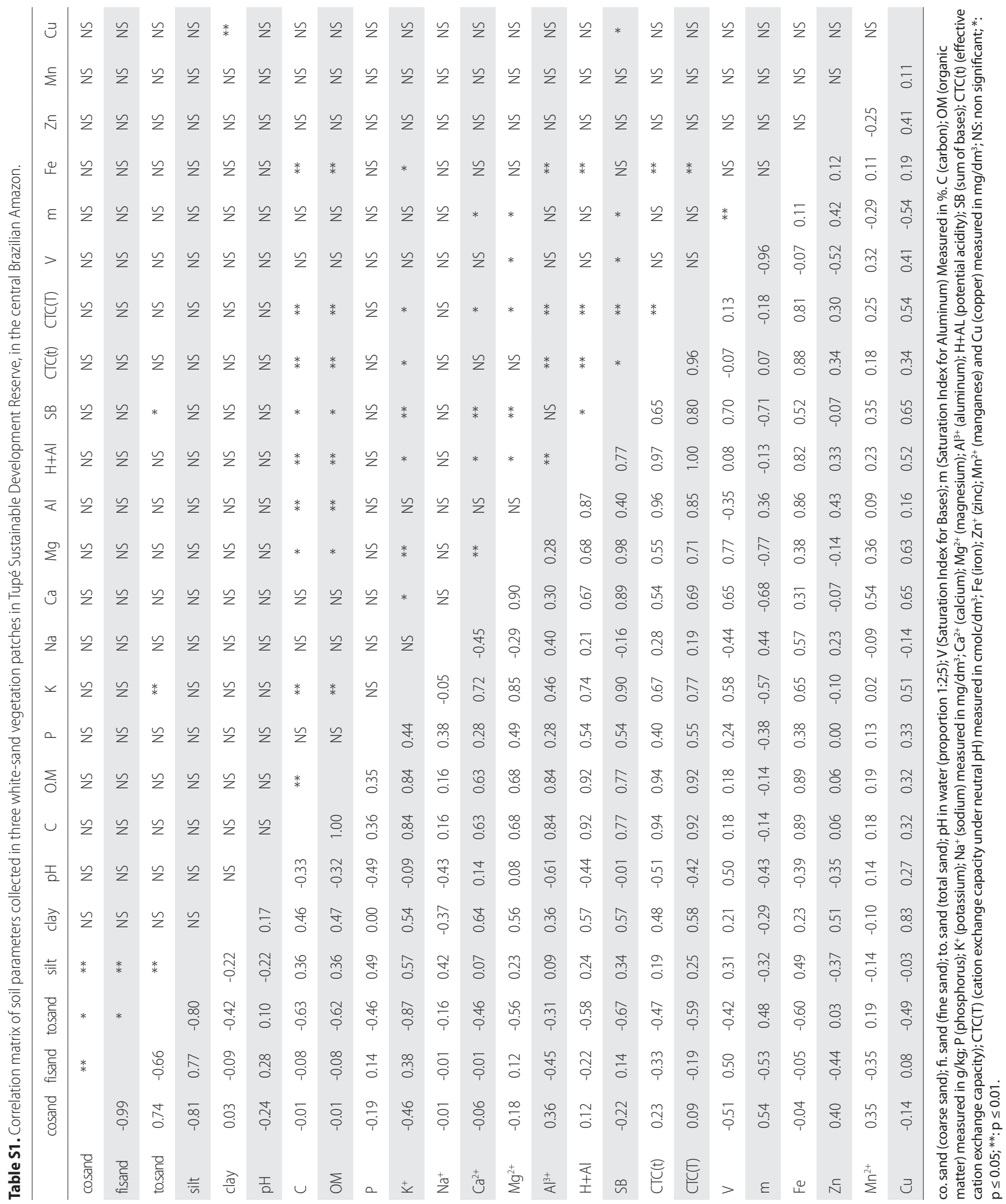


Table S2. Phytosociological parameters of species found in the three areas of white-sand vegetation sampled in Tupé Sustainable Development Reserve, central Brazilian Amazon. $\mathrm{N}$. = number of individuals, $\mathrm{N}$ Par = number of parcels in wich species occurred, $\mathrm{RDe}=$ Relative Density, $\mathrm{RDo}=$ Relative Dominance, $\mathrm{RFr}=\mathrm{Relative}$ Frequency, IVI = Importance Value Index. Voucher number refers to material deposited in the herbaria of Instituto Nacional de Pesquisas da Amazônia (INPA) and Instituto Federal do Amazonas (EAFM).

\begin{tabular}{|c|c|c|c|c|c|c|c|}
\hline Family/Species & $\mathrm{N}$ & N Par & RDe & RDo & $\mathrm{RFr}$ & IVI & Voucher Number \\
\hline \multicolumn{8}{|l|}{ ANACARDIACEAE } \\
\hline Spondias sp. & 3 & 2 & 0.08 & 0.06 & 0.46 & 0.60 & EAFM: $11194 / 11195$ \\
\hline Tapirira guianensis Aubl. & 24 & 6 & 0.61 & 1.19 & 1.38 & 3.18 & EAFM: 11192 \\
\hline Tapirira aff. guianensis Aubl. & 12 & 4 & 0.30 & 0.16 & 0.92 & 1.39 & EAFM: 11193 \\
\hline \multicolumn{8}{|l|}{ ANNONACEAE } \\
\hline Annona densicoma Mart. & 22 & 5 & 0.56 & 0.18 & 1.15 & 1.89 & INPA: 262118 / 262119 / 262120 EAFM: 11207 \\
\hline Guatteria schomburgkiana Mart. & 28 & 6 & 0.71 & 0.53 & 1.38 & 2.62 & INPA: 262116 / 262117 EAFM: 11205 / 11206 \\
\hline Xylopia barbata Hoffmanns. ex Mart. & 14 & 5 & 0.35 & 0.26 & 1.15 & 1.77 & EAFM: 11204 \\
\hline \multicolumn{8}{|l|}{ APOCYNACEAE } \\
\hline Aspidosperma excelsum Benth. & 1 & 1 & 0.03 & 0.23 & 0.23 & 0.49 & Not Collected \\
\hline Aspidosperma aff. verruculosum Müll.Arg. & 740 & 6 & 18.71 & 13.12 & 1.38 & 33.21 & EAFM: 11073 \\
\hline Lacmellea arborescens (Müll.Arg.) Markgr. & 32 & 7 & 0.81 & 0.50 & 1.61 & 2.92 & INPA: 262072 / 262073 / 262074 EAFM: 11074 \\
\hline Macoubea sprucei (Müll.Arg.) Markgr. & 28 & 5 & 0.71 & 0.24 & 1.15 & 2.10 & INPA: 262070 / 262071 EAFM: 11069 / 11070 \\
\hline Malouetia cf. flavescens (Willd. ex Roem. \& Schult.) Müll.Arg. & 1 & 1 & 0.03 & 0 & 0.23 & 0.26 & EAFM: 11072 \\
\hline \multicolumn{8}{|l|}{ ARALIACEAE } \\
\hline Scheffera decaphylla (Seem.) Harms & 20 & 3 & 0.51 & 0.39 & 0.69 & 1.59 & INPA: 262113 / 262114 EAFM: $11201 / 11202$ \\
\hline Schefflera umbrosa Frodin \& Fiaschi & 6 & 4 & 0.15 & 0.06 & 0.92 & 1.14 & INPA: 262115 - EAFM: 11203 \\
\hline \multicolumn{8}{|l|}{ ARECACEAE } \\
\hline Leopoldinia pulchra Mart. & 2 & 1 & 0.05 & 0.02 & 0.23 & 0.30 & Not Collected \\
\hline Mauritiella armata (Mart.) Burret & 41 & 2 & 1.04 & 1.67 & 0.46 & 3.17 & Not Collected \\
\hline Oenocarpus bataua Martius. & 5 & 1 & 0.13 & 0.23 & 0.23 & 0.59 & Not Collected \\
\hline \multicolumn{8}{|l|}{ BURSERACEAE } \\
\hline Protium hebetatum Daly & 5 & 2 & 0.13 & 0.07 & 0.46 & 0.66 & EAFM: 11141 \\
\hline Protium heptaphyllum (Aubl.) Marchand & 50 & 5 & 1.26 & 0.24 & 1.15 & 2.66 & INPA: 262094 / 262095 EAFM: 11139 / 11139 \\
\hline Protium paniculatum var. modestum Daly & 336 & 5 & 8.49 & 5.63 & 1.15 & 15.27 & INPA: 262091 / 262092 EAFM: 11135 / 11136 \\
\hline Protium aff. spruceanum (Benth.) Engl. & 8 & 2 & 0.20 & 0.09 & 0.46 & 0.75 & INPA: 262093 - EAFM: 11137 \\
\hline Protium sp. & 6 & 1 & 0.15 & 0.05 & 0.23 & 0.44 & EAFM: 11140 \\
\hline Trattinnickia burserifolia Mart. & 16 & 7 & 0.40 & 0.25 & 1.61 & 2.27 & INPA: 262090 - EAFM: 11133 / 11134 \\
\hline Trattinnickia sp. & 1 & 1 & 0.03 & 0 & 0.23 & 0.26 & EAFM:11132 \\
\hline \multicolumn{8}{|l|}{ CHRYSOBALANACEAE } \\
\hline Hirtella hispidula Miq. & 8 & 2 & 0.20 & 0.25 & 0.46 & 0.91 & EAFM: 11131 \\
\hline Licania gracilipes Taub. & 1 & 1 & 0.03 & 0.05 & 0.23 & 0.31 & EAFM: 11130 \\
\hline Licania lata J.F.Macbr. & 109 & 3 & 2.76 & 1.70 & 0.69 & 5.15 & EAFM: $11128 / 11129$ \\
\hline Licania sp.1 & 4 & 2 & 0.10 & 0.16 & 0.46 & 0.72 & EAFM: 11126 \\
\hline Licania sp.2 & 1 & 1 & 0.03 & 0 & 0.23 & 0.26 & EAFM: 11127 \\
\hline \multicolumn{8}{|l|}{ CLUSIACEAE } \\
\hline Clusia insignis Mart. & 7 & 4 & 0.18 & 0.29 & 0.92 & 1.39 & EAFM: 10926 \\
\hline Clusia nemorosa G.Mey. & 116 & 7 & 2.93 & 0.66 & 1.61 & 5.20 & INPA: 262057 / 262058 - EAFM: 10927 / 10928 \\
\hline Clusia renggerioides Planch. \& Triana & 8 & 4 & 0.20 & 0.26 & 0.92 & 1.38 & INPA: 262056 - EAFM: 10924 / 10925 \\
\hline Clusia aff. spathulaefolia Engl. & 116 & 6 & 2.93 & 0.86 & 1.38 & 5.17 & INPA: 262059 - EAFM: 10929 \\
\hline Tovomita acutiflora M.S. de Barros \& G. Mariz & 21 & 3 & 0.53 & 0.16 & 0.69 & 1.38 & INPA: 262060 / 262061 / 262062 EAFM: 10930 \\
\hline \multicolumn{8}{|l|}{ COMBRETACEAE } \\
\hline Buchenavia macrophylla Eichler & 4 & 4 & 0.10 & 0.15 & 0.92 & 1.17 & EAFM: 10952 \\
\hline Buchenavia sp. & 2 & 1 & 0.05 & 0.04 & 0.23 & 0.32 & EAFM: 10953 \\
\hline
\end{tabular}


Table S2. Continued.

\begin{tabular}{|c|c|c|c|c|c|c|c|}
\hline Family/Species & N & N Par & RDe & RDo & RFr & IVI & Voucher Number \\
\hline \multicolumn{8}{|l|}{ DICHAPETALACEAE } \\
\hline Tapura lanceolata (Ducke) Rizzini & 4 & 2 & 0.10 & 0.11 & 0.46 & 0.67 & EAFM: 10950 \\
\hline \multicolumn{8}{|l|}{ EBENACEAE } \\
\hline Diospyros sp. & 9 & 4 & 0.23 & 0.12 & 0.92 & 1.27 & EAFM: $10933 / 10934$ \\
\hline \multicolumn{8}{|l|}{ ELAEOCARPACEAE } \\
\hline Sloanea sp. & 1 & 1 & 0.03 & 0.04 & 0.23 & 0.30 & EAFM: 11078 \\
\hline \multicolumn{8}{|l|}{ EUPHORBIACEAE } \\
\hline Alchornea discolor Poepp. & 4 & 2 & 0.10 & 0.02 & 0.46 & 0.58 & EAFM: 11179 \\
\hline Aparisthmium cordatum (A.Juss.) Baill. & 3 & 1 & 0.08 & 0.02 & 0.23 & 0.33 & EAFM: 11178 \\
\hline Conceveiba terminalis (Baill.) Müll.Arg. & 85 & 8 & 2.15 & 3.93 & 1.84 & 7.92 & INPA: 262105 - EAFM: $11181 / 11182$ \\
\hline Mabea subsessilis Pax \& K.Hoffm. & 1 & 1 & 0.03 & 0.01 & 0.23 & 0.27 & EAFM: 11180 \\
\hline \multicolumn{8}{|l|}{ FABACEAE } \\
\hline Abarema adenophora (Ducke) Barneby \& J.W.Grimes & 4 & 1 & 0.10 & 0.07 & 0.23 & 0.40 & EAFM: 11095 \\
\hline Aldina heterophylla Spruce ex Benth. & 170 & 9 & 4.30 & 28.04 & 2.07 & 34.41 & EAFM: $11103 / 11104$ \\
\hline Andira micrantha Ducke & 3 & 2 & 0.08 & 0.07 & 0.46 & 0.61 & EAFM: $11101 / 11102$ \\
\hline Dimorphandra vernicosa Spreng. ex Benth. & 30 & 3 & 0.76 & 0.79 & 0.69 & 2.24 & INPA: 262081 / 262082 - EAFM: $11099 / 11100$ \\
\hline Diplotropis aff. purpurea (Rich.) Amshoff & 2 & 1 & 0.05 & 0.01 & 0.23 & 0.29 & EAFM: 11096 \\
\hline Hymenolobium modestum Ducke & 1 & 1 & 0.03 & 0.01 & 0.23 & 0.26 & EAFM: 11094 \\
\hline Inga lateriflora Miq. & 19 & 5 & 0.48 & 0.34 & 1.15 & 1.97 & INPA: 262083 - EAFM: 11105 \\
\hline Macrolobium arenarium Ducke & 77 & 5 & 1.95 & 2.23 & 1.15 & 5.33 & EAFM: 11087 \\
\hline Macrolobium campestre Huber & 1 & 1 & 0.03 & 0.02 & 0.23 & 0.28 & EAFM: 11085 \\
\hline Macrolobium limbatum Spruce ex Benth. & 1 & 1 & 0.03 & 0.01 & 0.23 & 0.26 & EAFM: 11086 \\
\hline Ormosia costulata (Miq.) Kleinh. & 5 & 4 & 0.13 & 0.03 & 0.92 & 1.08 & EAFM: $11097 / 11098$ \\
\hline Parkia igneiflora Ducke & 64 & 6 & 1.62 & 1.23 & 1.38 & 4.23 & EAFM: 11092 \\
\hline Swartzia lamellata Ducke & 23 & 5 & 0.58 & 0.50 & 1.15 & 2.23 & EAFM: $11088 / 11089$ \\
\hline Swartzia tessmannii Harms & 105 & 7 & 2.65 & 1.85 & 1.61 & 6.11 & INPA: 262080 - EAFM: 11090 / 11091 \\
\hline Tachigali glauca Tul. & 1 & 1 & 0.03 & 0 & 0.23 & 0.26 & EAFM: 11093 \\
\hline \multicolumn{8}{|l|}{ HUMIRIACEAE } \\
\hline Humiria balsamifera (Aubl.) J.St.-Hil. & 20 & 4 & 0.51 & 1.71 & 0.92 & 3.14 & EAFM: 11184 \\
\hline Sacoglottis sp. & 3 & 2 & 0.08 & 0.08 & 0.46 & 0.62 & EAFM: 11185 \\
\hline \multicolumn{8}{|l|}{ ICACINACEAE } \\
\hline Discophora guianensis Miers & 10 & 3 & 0.25 & 0.09 & 0.69 & 1.03 & INPA: 262077 / 262078 / 262079 EAFM: 11082 \\
\hline \multicolumn{8}{|l|}{ LAMIACEAE } \\
\hline Vitex triflora Vahl & 57 & 7 & 1.44 & 1.6 & 1.61 & 4.66 & EAFM: 10946 \\
\hline \multicolumn{8}{|l|}{ LAURACEAE } \\
\hline Aniba hostmanniana (Nees) Mez & 1 & 1 & 0.03 & 0.01 & 0.23 & 0.27 & EAFM: 11159 \\
\hline Aniba santalodora Ducke & 32 & 6 & 0.81 & 1.20 & 1.38 & 3.39 & INPA: 262099 - EAFM: $11160 / 11161$ \\
\hline Endlicheria arenosa Chanderb. & 43 & 5 & 1.09 & 0.28 & 1.15 & 2.52 & INPA: 262100 - EAFM: 11162 \\
\hline Licaria aff. chrysophylla (Meisn.) Kosterm. & 1 & 1 & 0.03 & 0.03 & 0.23 & 0.28 & EAFM: 11174 \\
\hline Licaria sp.1 & 8 & 2 & 0.20 & 0.20 & 0.46 & 0.86 & INPA: 262104 - EAFM: 11177 \\
\hline Licaria sp.2 & 1 & 1 & 0.03 & 0.02 & 0.23 & 0.27 & EAFM: 11175 \\
\hline Licaria sp.3 & 1 & 1 & 0.03 & 0.01 & 0.23 & 0.26 & EAFM: 11176 \\
\hline Ocotea aciphylla (Nees \& Mart.) Mez & 25 & 5 & 0.63 & 0.92 & 1.15 & 2.70 & EAFM: $11165 / 11166$ \\
\hline Ocotea amazonica (Meisn.) Mez & 19 & 3 & 0.48 & 0.15 & 0.69 & 1.32 & EAFM: $11169 / 11170$ \\
\hline Ocotea oblonga (Meisn.) Mez & 2 & 1 & 0.05 & 0.02 & 0.23 & 0.30 & EAFM: 11168 \\
\hline Ocotea olivaceae A.C.Sm. & 1 & 1 & 0.03 & 0.01 & 0.23 & 0.26 & EAFM: 11167 \\
\hline Ocotea sp.1 & 16 & 6 & 0.40 & 0.08 & 1.38 & 1.87 & INPA: 262101 / 262102 / 262103 EAFM: 11171 \\
\hline Ocotea sp.2 & 1 & 1 & 0.03 & 0.01 & 0.23 & 0.27 & EAFM: 11163 \\
\hline Ocotea sp.3 & 3 & 1 & 0.08 & 0.02 & 0.23 & 0.32 & EAFM: 11164 \\
\hline
\end{tabular}


Table S2. Continued.

\begin{tabular}{|c|c|c|c|c|c|c|c|}
\hline Family/Species & $\mathrm{N}$ & NPar & $\mathrm{RDe}$ & RDo & $\mathrm{RFr}$ & $\mid \mathrm{VI}$ & Voucher Number \\
\hline \multicolumn{8}{|l|}{ LECYTHIDACEAE } \\
\hline Allantoma decandra (Ducke) S.A.Mori et al. & 3 & 1 & 0.08 & 0.14 & 0.23 & 0.45 & EAFM: 10951 \\
\hline \multicolumn{8}{|l|}{ LINACEAE } \\
\hline Hebepetalum humiriifolium (G.Planch.) Benth. & 8 & 2 & 0.20 & 0.15 & 0.46 & 0.81 & EAFM: $11066 / 11067$ \\
\hline Roucheria columbiana Hallier & 10 & 3 & 0.25 & 0.10 & 0.69 & 1.04 & INPA: 262069 - EAFM: 11068 \\
\hline \multicolumn{8}{|l|}{ MALPHIGUIACEAE } \\
\hline Byrsonima laevis Nied. & 34 & 5 & 0.86 & 0.47 & 1.15 & 2.48 & INPA: 262064 - EAFM: 10937 / 10938 / 10940 \\
\hline Byrsonima aff. laevis Nied. & 32 & 3 & 0.81 & 0.49 & 0.69 & 1.99 & INPA: 262065 - EAFM: 10939 / 10941 \\
\hline \multicolumn{8}{|l|}{ MALVACEAE } \\
\hline Pachira faroensis (Ducke) W.S.Alverson & 6 & 2 & 0.15 & 0.43 & 0.46 & 1.04 & INPA: 262068 - EAFM: 10947 / 10948 \\
\hline Scleronema micranthum (Ducke) Ducke & 6 & 3 & 0.15 & 0.20 & 0.69 & 1.04 & EAFM: 10949 \\
\hline \multicolumn{8}{|l|}{ MELASTOMATACEAE } \\
\hline Henriettea maroniensis Sagot & 2 & 1 & 0.05 & 0.01 & 0.23 & 0.29 & INPA: 262112 - EAFM: 11199 \\
\hline Melastomatacea sp. & 1 & 1 & 0.03 & 0.02 & 0.23 & 0.28 & EAFM: 11200 \\
\hline Miconia argyrophylla DC. & 58 & 6 & 1.47 & 0.30 & 1.38 & 3.15 & INPA: 262109 / $262110 / 262111$ EAFM: 11196 \\
\hline \multicolumn{8}{|l|}{ MELIACEAE } \\
\hline Trichilia sp. & 1 & 1 & 0.03 & 0 & 0.23 & 0.26 & EAFM: 11125 \\
\hline \multicolumn{8}{|l|}{ MORACEAE } \\
\hline Brosimum guianense (Aubl.) Huber & 6 & 3 & 0.15 & 0.06 & 0.69 & 0.91 & INPA: 262084 / 262085 EAFM: 11107 / 11108 \\
\hline Brosimum sp. & 1 & 1 & 0.03 & 0 & 0.23 & 0.26 & EAFM: 11106 \\
\hline Ficus greiffiana Dugand & 6 & 5 & 0.15 & 0.25 & 1.15 & 1.55 & INPA: 262087 - EAFM: 11112 \\
\hline Ficus mathewsii (Miq.) Miq. & 1 & 1 & 0.03 & 1.03 & 0.23 & 1.29 & EAFM: 11111 \\
\hline Ficus paraensis (Miq.) Miq. & 1 & 1 & 0.03 & 0 & 0.23 & 0.26 & EAFM: 11110 \\
\hline Ficus sp. & 1 & 1 & 0.03 & 0.83 & 0.23 & 1.08 & INPA: 262086 - EAFM: 11109 \\
\hline Helicostylis scabra (J.F.Macbr.) C.C.Berg & 1 & 1 & 0.03 & 0.01 & 0.23 & 0.26 & EAFM: 11113 \\
\hline \multicolumn{8}{|l|}{ MYRISTICACEAE } \\
\hline Iryanthera sp. & 1 & 1 & 0.03 & 0.01 & 0.23 & 0.26 & EAFM: 11114 \\
\hline Virola calophylla Warb. & 1 & 1 & 0.03 & 0.01 & 0.23 & 0.26 & EAFM: 11115 \\
\hline Virola pavonis (A.DC.) A.C.Sm. & 2 & 1 & 0.05 & 0.16 & 0.23 & 0.45 & EAFM: 11116 \\
\hline \multicolumn{8}{|l|}{ MYRTACEAE } \\
\hline Eugenia moschata (Aubl.) Nied. ex T.Durand \& B.D.Jacks. & 2 & 2 & 0.05 & 0.01 & 0.46 & 0.52 & EAFM: 11214 \\
\hline Eugenia sp.1 & 1 & 1 & 0.03 & 0 & 0.23 & 0.26 & EAFM: 11215 \\
\hline Eugenia sp.2 & 1 & 1 & 0.03 & 0.01 & 0.23 & 0.26 & EAFM: 11216 \\
\hline Marlierea caudata McVaugh & 2 & 1 & 0.05 & 0.02 & 0.23 & 0.30 & EAFM: 11217 \\
\hline Myrcia aff. amazonica DC. & 2 & 2 & 0.05 & 0.11 & 0.46 & 0.62 & INPA: 262121 - EAFM: 11210 \\
\hline Myrcia sp.1 & 2 & 2 & 0.05 & 0.01 & 0.46 & 0.53 & EAFM: 11212 \\
\hline Myrcia sp.2 & 1 & 1 & 0.03 & 0.01 & 0.23 & 0.27 & EAFM: 11213 \\
\hline \multicolumn{8}{|l|}{ NYCTAGINACEAE } \\
\hline Guapira sp. & 17 & 6 & 0.43 & 0.34 & 1.38 & 2.15 & INPA: 262107 - EAFM: $11187 / 11188$ \\
\hline \multicolumn{8}{|l|}{ OCHNACEAE } \\
\hline Ouratea spruceana Engl. & 17 & 6 & 0.43 & 0.11 & 1.38 & 1.92 & INPA: 262108 - EAFM: $11190 / 11191$ \\
\hline \multicolumn{8}{|l|}{ OLACACEAE } \\
\hline Dulacia candida (Poepp.) Kuntze & 29 & 5 & 0.73 & 0.20 & 1.15 & 2.08 & INPA: 262063 - EAFM: 10935 / 10936 \\
\hline \multicolumn{8}{|l|}{ OPILIACEAE } \\
\hline Agonandra aff. silvatica Ducke & 1 & 1 & 0.03 & 0.03 & 0.23 & 0.28 & EAFM: 11065 \\
\hline \multicolumn{8}{|l|}{ PERACEAE } \\
\hline Pera bicolor (Klotzsch) Müll.Arg. & 8 & 4 & 0.20 & 0.22 & 0.92 & 1.34 & INPA: 262106 - EAFM: 11183 \\
\hline
\end{tabular}


Table S2. Continued.

\begin{tabular}{|c|c|c|c|c|c|c|c|}
\hline Family/Species & $\mathrm{N}$ & N Par & RDe & RDo & RFr & IVI & Voucher Number \\
\hline \multicolumn{8}{|l|}{ PRIMULACEAE } \\
\hline Cybianthus guyanensis (A.DC.) Miq. & 7 & 2 & 0.18 & 0.04 & 0.46 & 0.68 & INPA: 262075 / 262076 EAFM: 11080 / 11081 \\
\hline Cybianthus sp. & 21 & 5 & 0.53 & 0.34 & 1.15 & 2.02 & EAFM: 11079 \\
\hline \multicolumn{8}{|l|}{ Rhizophoraceae } \\
\hline Sterigmapetalum colombianum Monach. & 27 & 6 & 0.68 & 0.54 & 1.38 & 2.61 & EAFM: 11186 \\
\hline \multicolumn{8}{|l|}{ RUBIACEAE } \\
\hline Duroia saccifera (Schult. \& Schult.f.) K.Schum. & 37 & 5 & 0.94 & 0.24 & 1.15 & 2.33 & INPA: 262125 / 262126 / 262127 / 262128 \\
\hline Kutchubaea oocarpa (Spruce ex Standl.) C.H.Perss. & 4 & 2 & 0.10 & 0.02 & 0.46 & 0.58 & INPA: 262131 / 262132 EAFM: 11228 / 11229 \\
\hline Kutchubaea sericantha Standl. & 110 & 7 & 2.78 & 1.17 & 1.61 & 5.56 & INPA: 262129 / 262130 EAFM: 11226 / 11227 \\
\hline Pagamea duckei Standl. & 217 & 7 & 5.49 & 1.19 & 1.61 & 8.29 & INPA: 262123 / 262124 EAFM: 11220 / 11221 \\
\hline Pagamea guianensis Aubl. & 3 & 2 & 0.08 & 0.04 & 0.46 & 0.57 & INPA: 262122 - EAFM: 11218 \\
\hline \multicolumn{8}{|l|}{ SAPINDACEAE } \\
\hline Matayba inelegans Spruce ex Radlk. & 4 & 2 & 0.10 & 0.02 & 0.46 & 0.58 & INPA: 262088 / 262089 EAFM: $11118 / 11119$ \\
\hline Matayba opaca Radlk. & 59 & 7 & 1.49 & 0.61 & 1.61 & 3.72 & EAFM: 11120 \\
\hline Matayba sp. & 2 & 1 & 0.05 & 0.01 & 0.23 & 0.29 & EAFM: 11117 \\
\hline Talisia firma Radlk. & 8 & 3 & 0.20 & 0.08 & 0.69 & 0.97 & EAFM: $11121 / 11122$ \\
\hline Talisia ghilleana Acev.-Rodr. & 4 & 2 & 0.10 & 0.02 & 0.46 & 0.58 & EAFM: 11123 \\
\hline Vouarana guianensis Aubl. & 2 & 2 & 0.05 & 0.01 & 0.46 & 0.52 & EAFM: 11124 \\
\hline \multicolumn{8}{|l|}{ SAPOTACEAE } \\
\hline Chrysophyllum cuneifolium (Rudge) A.DC. & 30 & 4 & 0.76 & 0.31 & 0.92 & 1.99 & INPA: 262098 - EAFM: 11154 \\
\hline Chrysophyllum sanguinolentum (Pierre) Baehni & 24 & 6 & 0.61 & 0.62 & 1.38 & 2.61 & EAFM: 11153 \\
\hline Chrysophyllum sp. & 1 & 1 & 0.03 & 0.04 & 0.23 & 0.30 & EAFM: 11152 \\
\hline Manilkara bidentata (A.DC.) A.Chev. & 129 & 8 & 3.26 & 4.02 & 1.84 & 9.13 & EAFM: $11157 / 11158$ \\
\hline Micropholis aff. guyanensis (A.DC.) Pierre & 1 & 1 & 0.03 & 0 & 0.23 & 0.26 & EAFM: 11155 \\
\hline Pouteria cuspidata (A.DC.) Baehni & 1 & 1 & 0.03 & 0.02 & 0.23 & 0.27 & EAFM: 11149 \\
\hline Pouteria aff. cuspidata (A.DC.) Baehni & 2 & 1 & 0.05 & 0.11 & 0.23 & 0.40 & EAFM: 11148 \\
\hline Pouteria aff. elegans (A.DC.) Baehni & 80 & 5 & 2.02 & 1.64 & 1.15 & 4.82 & INPA: 262096 - EAFM: 11142 / 11143 \\
\hline Pouteria oblanceolata Pires & 23 & 3 & 0.58 & 0.63 & 0.69 & 1.90 & INPA: 262097 / EAFM: 11150 \\
\hline Pouteria sp.1 & 20 & 5 & 0.51 & 0.35 & 1.15 & 2.01 & EAFM: $11144 / 11145$ \\
\hline Pouteria sp.2 & 1 & 1 & 0.03 & 0.03 & 0.23 & 0.28 & EAFM: 11146 \\
\hline Pouteria sp.3 & 1 & 1 & 0.03 & 0.01 & 0.23 & 0.27 & EAFM: 11147 \\
\hline Pradosia schomburgkiana (A.DC.) Cronquist & 70 & 7 & 1.77 & 0.98 & 1.61 & 4.36 & EAFM: 11156 \\
\hline Sapotaceae sp. & 1 & 1 & 0.03 & 0.20 & 0.23 & 0.46 & Not Collected \\
\hline \multicolumn{8}{|l|}{ SIMAROUBACEAE } \\
\hline Simaba guianensis Aubl. & 91 & 6 & 2.30 & 3.21 & 1.38 & 6.89 & EAFM: 10942 \\
\hline Simarouba amara Aubl. & 48 & 7 & 1.21 & 1.66 & 1.61 & 4.49 & INPA: 262066 - EAFM: 10943 / 10944 \\
\hline \multicolumn{8}{|l|}{ URTICACEAE } \\
\hline Coussapoa asperifolia Trécul & 1 & 1 & 0.03 & 0.01 & 0.23 & 0.26 & EAFM: 11077 \\
\hline \multicolumn{8}{|l|}{ VOCHYSIACEAE } \\
\hline Vochysia sp. & 1 & 1 & 0.03 & 0.01 & 0.23 & 0.26 & EAFM: 11189 \\
\hline
\end{tabular}

